\title{
A survey of zoonotic nematodes of commercial key fish species from major European fishing grounds - introducing the FP7 PARASITE exposure assessment study
}

Arne Levsen $^{\mathrm{a} *}$, Cecilie S. Svanevik ${ }^{\mathrm{a}}$, Paolo Cipriani ${ }^{\mathrm{b}, \mathrm{c}}$, Simonetta Mattiucci ${ }^{\mathrm{b}, \mathrm{c}}$, Mélanie Gay ${ }^{\mathrm{d}}$, Lee C. Hastie $^{\mathrm{e}}$, Ivana Bušelić ${ }^{\mathrm{g}}$, Ivona Mladineo ${ }^{\mathrm{g}}$, Horst Karl ${ }^{\mathrm{h}}$, Ute Ostermeyer ${ }^{\mathrm{h}}$, Kurt Buchmanni, Dánjal P. Højgaard ${ }^{k}$, Ángel F. González ${ }^{m}$, Santiago Pascual ${ }^{m}$, Graham J. Pierce $^{\mathrm{e}, \mathrm{f}, \mathrm{m}}$

${ }^{a}$ National Institute of Nutrition and Seafood Research (NIFES), PO Box 2029 Nordnes, 5817 Bergen, Norway

${ }^{\mathrm{b} D}$ Department of Ecological and Biological Sciences Tuscia University, Largo dell'Università s.n.c., 01100 Viterbo, Italy.

'Department of Public Health and Infectious Diseases, Section of Parasitology, Sapienza University of Rome, P.le Aldo Moro, 5, 00185 Rome, Italy

${ }^{d}$ French Agency for Food, Environmental and Occupational Health and Safety (ANSES), Laboratory for Food Safety, Bld Bassin Napoléon, 62200 Boulogne-sur-mer, France

e Oceanlab, University of Aberdeen, Main Street, Newburgh, Aberdeenshire, AB41 6AA, UK

${ }^{f}$ CESAM \& Departamento de Biologia, Universidade de Aveiro, 3810-193 Aveiro, Portugal

${ }^{\mathrm{g}}$ Institute of Oceanography and Fisheries (IZOR), Setaliste I. Mestrovica 63, 21000 Split, Croatia

${ }^{\mathrm{h}}$ Max Rubner Institute, Federal Research Institute of Nutrition and Food, Department of Safety and Quality of Milk and Fish Products, Hermann-Weigmann-Straße 1, 24103 Kiel, Germany

'Department of Veterinary and Animal Sciences, Faculty of Health and Medical Sciences, University of Copenhagen, Stigbøjlen 7, DK-1870 Frederiksberg C., Denmark

${ }^{k}$ Faroe Marine Research Institute (FAMRI) - Havstovan, PO Box 305, Nóatún 1, 110 Tórshavn, Faroe Islands

mInstitute of Marine Sciences (IIM-CSIC), Eduardo Cabello 6, 36208 Vigo, Spain

*Corresponding author: Arne Levsen; E-mail address: arne.levsen@nifes.no 


\section{Abstract}

Harvesting and exploiting limited fisheries resources in a sustainable manner also implies achieving maximum added value from the raw material. However, the presence of parasites in the products may adversely affect consumer perception and/or pose a direct health hazard. As a major steppingstone of the PARASITE project, an epidemiological survey was carried out to provide the basis for analysis and prediction of consumer exposure risk due to the presence of anisakid nematodes in fish from European wild-catch fisheries. The project consisted of nine separate workpackages (WP) where the exposure risk assessment survey was organized within WP2. The surveillance task also provided the data or samples needed for data management and sample storage (WP3, Biobank), molecular and genetic parasite species identification (WP4), and statistical modelling and inference (WP8). In total 17,760 fish belonging to 16 teleost species were examined for anisakids, with special emphasis on economically and ecologically important species such as Atlantic mackerel, herring, European hake, Atlantic cod and anchovy. The target fish species were sampled at four major European fishing areas including the Barents Sea, North Sea, Baltic Sea, Grand Sole Bank, waters off NW Spain and Portugal, central and western parts of the Mediterranean Sea, and the Adriatic Sea. Thus, the survey represents the largest and most comprehensive epidemiological data compilation of anisakids ever generated in terms of geographical range as well as number of fish host species and sample size. An important requirement of the survey was the use of commonly accepted nematode detection methods, i.e. the UV-press method or artificial digestion, to quantify infection level and spatial distribution of anisakid larvae in the target fish species. The basic layout, set-up and principles of the method, along with a discussion of possible source of errors are described. Additionally, the molecular and genetic markers which were used to identify and characterize different species and populations of anisakids from the targeted fish host species and geographical areas, are reviewed as well. Some basic parasite infection characteristics of each fish host species, and any relationships with the presumably most important infection predictors, i.e. fish host body size and fishing locality, are presented and discussed. Emphasis is put on anisakid occurrence in the flesh of the fish. Based on the findings, a graphical exposure risk profile is introduced, including fish species or products thereof, which due to common processing or preparation practices, are at highest risk to act as source of anisakiasis in Europe.

Key words:

EU fisheries, Zoonotic parasites, Anisakis spp., Surveillance, Atlantic, Mediterranean 


\section{Introduction}

The EU fisheries industry is the fifth largest in the world. In the European Union, close to 5 million tons of wild fish catches are processed every year. Fishing and fish processing provide jobs for at least 275,000 people. Moreover, the EU is among the leading fish markets in the world with imports accounting for approximately $€ 21$ billion in 2014 , more than $40 \%$ of world fish imports in value, with increasing trend. It should be noted, however, that Norway as an EU third country accounts for $23 \%$ of the EU seafood imports alone. The average consumption of fisheries products in the EU-28 countries was $24.9 \mathrm{~kg} /$ person in 2011. The annual per capita consumption rate varies greatly, however, from $5.3 \mathrm{~kg}$ in Hungary to $56.8 \mathrm{~kg}$ in Portugal (the above statistical overview was retrieved on $4^{\text {th }}$ April 2017 from https://ec.europa.eu/fisheries/sites/fisheries/files/docs/body/pcp_en.pdf).

Nevertheless, consumers expect safe and healthy fish and fishery products. However, some of the most important fish species caught by the European fishing industries are at risk of carrying parasites when put on the market. In Europe, anisakid nematodes are the most relevant group of parasites in terms of consumer health risk and product quality, with Anisakis and Pseudoterranova as the genera of greatest concern because several species are considered a human health hazard (Mattiucci et al., 2017a). The term anisakiasis refers to the zoonotic disease provoked through accidental ingestion of viable larvae of certain Anisakis species which infect the edible parts of fish or squid. Among the nine nominal species belonging to the genus Anisakis (Mattiucci and Nascetti, 2008; Mattiucci et al., 2014), A. simplex (sensu stricto) and A. pegreffii have been confirmed to cause disease in humans (D'Amelio et al., 1999; Umehara et al., 2007; Mattiucci et al., 2011, 2013; Lim et al., 2015; Mladineo et al., 2016; Bao et al., 2017). It was further demonstrated that $A$. pegreffii may provoke gastric (GA), intestinal (IA) and gastro-allergic anisakiasis (GAA) (Mattiucci et al., 2011, 2013; Lim et al., 2015; Mladineo et al., 2016), while both $A$. simplex (s. s.) and A. pegreffii larvae may cause allergic reactions in humans (Daschner et al., 2012). Although international regulations, e.g. EU No. 1276/2011, demand deep-freezing for at least $24 \mathrm{~h}$ of any fishery product to be consumed raw or semi-raw, this so-called freezing requirement is not necessarily practiced by private households or local guesthouses and restaurants. Thus, consumption of local or privately prepared dishes based on fresh, only lightly processed fish such as boquerones in Spain and marinated anchovies in Spain and Italy, probably represents a major source of anisakiasis in Europe.

Self-control programs such as HACCP (hazard analysis and critical control points) procedures in the fish industry are hampered by the fact that the epidemiology of anisakid parasites in fish caught and marketed in Europe is not well understood. The collection of data on the complete life cycle, geographical and seasonal distribution, prevalence, intensity, and infection site of parasites of public 
health importance in wild fish stocks and fishery products has so far been based mainly on nonsystematic and opportunistic sampling, lacking appropriate time series or monitoring programs coordinated on a pan-European scale. Therefore, a well-designed systematic epidemiological survey of the economically most important fish species and stocks from European fishing grounds could provide the basis for analyzing and modelling parasite prevalence and abundance.

In fish, the majority of Anisakis larvae are typically seen as whitish to greyish, flat and tight coils, measuring a few $\mathrm{mm}$ across. Larvae that reside in the fish flesh are very hard to detect by the naked eye since they are often transparent and may have penetrated deeply into the fillets. Moreover, the larval occurrence in terms of their abundance and spatial distribution seems largely to depend on fish host species and their respective feeding behavior. Thus, piscivorous species such as adult hake and cod are usually more heavily infected with anisakid larvae compared to strict plankton feeders such as sardine, anchovy and capelin (for reviews of the literature, see Mladineo and Poljak, 2014; Šimat et al., 2015; Cipriani et al., 2016; Levsen et al., 2016; Zorica et al., 2016). However, we know only little about the spatial distribution of anisakid larvae in various economically important fish species, i.e. where in the fish the larvae primarily reside. This is especially important whenever anisakid larvae occur in the flesh (fillets and belly flaps) of fish.

The main objective of the anisakid exposure assessment work-package (WP2) of the PARASITE project was to provide comprehensive and comparable epidemiological data with respect to zoonotic parasites in the economically most important fish species or stocks originating from major European fishing grounds. The study focused on Anisakis species (mainly A. simplex and A. pegreffii), extending to other species such as Pseudoterranova decipiens (s. I.), Contraceacum osculatum (s. I.) and Hysterothylacium aduncum (non-zoonotic species but may have aesthetical quality reducing effect if present abundantly), where adequate data were available. Thus, the current report provides a basic overview of the methods which were commonly applied to detect anisakid nematodes in the actual fish samples, and to identify them molecularly to species level. The report further summarizes some basic epidemiological results with emphasis on larval occurrence in the fish flesh, and analyses through GAM modelling the relationships between larval occurrence and fish host body size which is already known to act as important driver of anisakid infection patterns in many fish species and fishing areas. Finally, we introduce a graphical exposure risk profile based on prevalence data of Anisakis spp. in the flesh of several fish species which are commonly prepared and consumed in a raw or only lightly processed state.

\section{Material and methods}




\subsection{Target fish species}

The primary decision criteria for the target fish species of the survey concerned their importance in terms of: 1) annual consumption volume/sales value, 2) significance for the fresh fish market, 3) basis for raw or semi-raw products such as sushi and sashimi, and 4) parasite history (e.g., former RASFF Rapid Alert System for Food and Feed - notifications). Thus, the pelagic fish species included in the survey were herring (Clupea harengus), sardine (Sardinus pilchardus), anchovy (Engraulis encrasicolus), Atlantic mackerel (Scomber scombrus), chub mackerel (S. colias) and blue whiting (Micromesistius poutassou). European hake (Merluccius merluccius), haddock (Melanogrammus aeglefinus), Atlantic cod (Gadus morhua) and monkfish (Lophius piscatorius and L. budegassa), in addition of two flatfish species - plaice (Pleuronectes platessa) and four-spotted megrim (Lepidorhombus boscii) - represented species preferring demersal habitats. On a smaller scale, or whenever available, we also investigated whiting (Merlangius merlangus), European sea bass (Dicentrarchus labrax) and silver scabbardfish (Lepidopus caudatus) since these, too, are commercially utilized on an industrial scale and are of importance in a number of major European seafood markets including Spain, UK, Italy and France. Three of the fish species to be included in the survey, i.e. Atlantic mackerel, blue whiting and hake, occur and are commercially utilized in all major European fishing areas except the Baltic Sea. Thus, the epidemiological data obtained from these species and areas have been particularly analyzed for the effect of specific habitat characteristics, geographical location/latitude and fish host migration patterns on the diversity and distribution of anisakid species.

\subsection{Sample size and fish host biometric data}

Fish host sample size varied among host species, sampling localities and sampling date/year. In general, smaller or medium sized species, e.g. anchovy, herring, mackerel or blue whiting were sampled and examined in greater quantities compared to larger species such as Atlantic cod, haddock or monkfish (Tab. 1). This was partly due to the fact that processing and UV-inspection of smaller fish is less labor- and time-intensive than examining larger fish. Additionally, samples of some other fish species, e.g. European sea bass, were more costly to obtain which again restricted their sample size.

For each fish, total round body weight (TW in g) and three body length measures (mm), i.e. total body length (TL), fork length (FL) and standard length $(\mathrm{SL})$ were recorded. For statistical analyses of the relationships between parasite infection and host biometric parameters, TW and/or TL were usually used as a descriptor of fish size. Other host biometric parameters that were recorded on a routine basis included fish gender, state of maturity, liver- and gonad weight (when feasible), as well 
as gross identification of stomach contents (empty/fish/crustaceans/mollusks/mud). TW and TL were also used to derive Fulton's condition index $\mathrm{K}\left(\mathrm{K}=\mathrm{W} * 10^{5} / \mathrm{L}^{3}\right)$.

\subsection{Sampling areas and sampling procedures}

Fish $(N=17,760)$ were sampled from 2012 to 2015 at various European fishing grounds. Fish were obtained during research cruises or regular commercial fishing operations and either processed and examined freshly on board the vessels, or deep-frozen immediately after catch for further processing and inspection at the respective laboratories on land. Some fish samples were also obtained at local fish markets or from local fishermen. Fig. 1 shows the ICES (Atlantic) or FAO (Mediterranean) fishing zones, highlighted dark-blue, in which the present fish samples were collected, while Tab. 1 provides an overview of the subsamples per fish species and particular ICES or FAO zone, along with names of the respective sampling areas.

\subsection{Parasite inspection methods}

In order to ensure best possible comparability of the nematode infection data, an important premise of the survey was, whenever feasible, to apply the same nematode inspection method throughout (only one surveyor applied the artificial digestion method, see Llarena-Reino et al. (2013) and references therein). This strategy probably reduced the effect of errors due to differences in detection efficiency and operator skills on the quality of data during sampling and parasite recording.

The UV/press-method is increasingly applied during systematic detection of nematode larvae in the flesh of fish, especially in large-scale scientific surveys (Levsen and Lunestad, 2010; Levsen and Karl, 2014; Klapper et al., 2015; Cipriani et al., 2016; Levsen et al., 2016). The method utilizes the fluorescence of frozen anisakid larvae (Pippy, 1970) and is based on visual inspection of flattened/pressed and subsequently deep-frozen fish fillets or viscera under UV-light (Karl and Leinemann, 1993). Like many other eukaryote organisms, anisakid nematodes accumulate lipofuscin, an auto-fluorescent pigment, within their cells. When the parasite cells break, the lipofuscin is released and upon excitement of the larvae with UV light, they fluoresce much brighter than the surrounding fish flesh. Prior to the pressing process, each fish is gutted and manually filleted before placing the visceral organs and both left and right-side flesh (fillets incl. belly flaps) into clear plastic bags. The samples are then pressed to 1-2 $\mathrm{mm}$ thick layers in a hydraulic or pneumatic pressing device (holding time approx. $5 \mathrm{sec}$ at 800-1400 kPa). The bags containing the pressed fillets or viscera are then deep-frozen prior to visual inspection under a $366 \mathrm{~nm}$ UV-light source equipped with both up- and down-light. Any anisakid larvae present appear as fluorescent spots in the samples; the brightness probably depending on various factors such as anisakid species involved, their size and 
141

142

143

144

145

146

147

148

149

150

151

152

153

154

155

156

157

158

159

160

161

162

163

164

165

166

167

168

169

170

171

172

173

174

175

age, the extent of encapsulation, and possibly, if the freezing-thawing cycle affects the integrity of the larvae.

Another advantage compared to the other widely used nematode inspection method, i.e. artificial digestion of soft tissue in an aqueous pepsin/ $\mathrm{HCl}$-solution, is that the UV-press method allows determination of the approximate larval infection site in both the flesh and the viscera. Thus, to facilitate the screening of the fish flesh, each flesh side (fillet + belly flap) is divided into 4 sections in the following manner; anterior ventral (AV) which corresponds roughly to belly flap, anterior dorsal (AD), posterior ventral (VP) and posterior dorsal (DP) (Fig. 2). After pressing, the different sections of each flesh side are readily recognized since - depending on fish species - the lateral line or red muscle area, or both, may be used as reference points/axis (Fig. 3). Whenever larger fish such as cod, haddock or monkfish were examined, each fillet or fish side was cut into smaller parts which were processed separately.

The nematode detection efficiency of the UV-press method was recently evaluated and compared with the artificial digestion method $(P e p s i n / H C l)$ in a ring trial (see Gómez-Morales et al., this volume). The results showed that the number of Anisakis spp. larvae recovered by the UV-press method had higher level of agreement (90\%) with the number of spiked larvae compared with the number of larvae recovered by artificial digestion (83\%).

The epidemiological data sets were organized as separate Microsoft Excel-workbooks per fish species examined. Each data set was consecutively updated according to the results from the genetic identification whenever new data were available. The data sets were subsequently transferred into the PARASITE BioBank data platform. In this way, the epidemiological data per fish species/stock and catching area, including Anisakis sibling species distribution, were available for geo-referenced data management.

\subsection{PARASITE biobank}

All fish host and parasite data generated during the PARASITE project were included in a biobank (BB) platform which was created to ensure traceability of the samples and associated data. The biobank consists of four nodes held in Vigo - Spain (repository and central node), Rome - Italy (DNA data and samples) and Madrid - Spain (protein and sera). The service is based on a non-profit scheme and includes data of more than 14000 specimens of different fish and cephalopod species, largely surpassing the collection of 220000 zoonotic parasites. Since 2015, the platform is ISO certified as ISO 9001. For details, see González et al. (submitted). 


\subsection{Genetic nematode species identification}

178 After initial gross identification to genus level based on morphology, various subsamples of

179 ascaridoid nematodes collected from all target fish hosts and sampling localities included in the

180 survey, were shipped in a frozen state to the Department of Public Health and Infectious Diseases of the Sapienza-University of Rome, for subsequent genetic identification. Samples of worms were stored frozen at $-50^{\circ} \mathrm{C}$ prior to analysis. Individual multi-locus genotypes of the ascaridoids were obtained by using distinct types of molecular markers. For specific identification of the nematodes of the genus Anisakis, the following genetic/molecular markers were applied: allozymes, sequence analysis of the mitochondrial cox2 (mtDNA cox2) gene, and sequence analysis of the elongation factor EF1 $\alpha-1$ nuclear DNA gene. For specific identification of the nematodes of the genera Pseudoterranova and Contracaecum, sequence analysis of the mitochondrial cox2 (mtDNA cox2) was used. Finally, the nematodes of the genus Hysterothylacium were identified by sequence analysis of the internal transcribed spacers (ITS rDNA) region.

For allozyme analysis of Anisakis spp. larvae, standard horizontal starch gel electrophoresis was performed to analyze the variation at four allozyme loci of diagnostic value in Anisakis species (Mattiucci et al., 1997, 2014). The actual loci were, 1) adenylate kinase (Adk-2, EC 2.7.4.3), 2) leucinealanine peptidase (Pep C-1, Pep C-2, EC 3.4.11), and, 3) superoxide dismutase (Sod-1, EC 1.15.1.1). Genetic analysis of the allozyme data was performed using BIOSYS-2 software, while any deviation from the Hardy-Weinberg equilibrium was estimated with a $\chi 2$ test. The tissue homogenates of Anisakis spp. larvae from the starch gel electrophoresis, were preserved at $-20^{\circ} \mathrm{C}$ and subsequently used to extract genomic DNA from each individual larva examined. Total DNA was extracted using the cetyltrithylammonium bromide method (CTAB) (for details, see Mattiucci et al., 2014), or with the DNeasy ${ }^{\circledR}$ Blood \& Tissue 120 kit (Qiagen) following the manufacturer's instructions. DNA was subsequently quantified by using the Qubit ${ }^{\mathrm{TM}}$ dsDNA HS Assay Kit with Qubit 2.0 (Invitrogen ${ }^{\mathrm{TM}}$ ).

The mitochondrial cytochrome c oxidase subunit II (cox2) gene was amplified using the primers $211 \mathrm{~F}$ (5'-TTTTCTAGTTATATAGATTGRTTYAT-3') and 210R (5'-CACCAACTCTTAAAATTA TC-3'), as previously reported by Mattiucci et al. $(2014,2015)$ and Timi et al. (2014) for the species of the genera Anisakis, Contracaecum and Pseudoterranova, respectively. Polymerase chain reaction (PCR) was carried out according to the procedures described by Mattiucci et al. (2014) and Timi et al. (2014). The sequences obtained for the mtDNA cox2 gene in the present study, were analyzed and aligned with the sequences of the same gene from other previously characterised anisakid species using GenBank Blast software and ClustalX (Thompson et al., 1997). 
212 For the elongation factor (EF1 $\alpha-1 \mathrm{nDNA})$ nuclear gene which was studied in the sibling species of the

213 A. simplex (s. I.) complex, the primers EF-F (5'-TCCTCAAGCGTTGTTATCTGTT-3') and EF-R (5'-

214 AGTTTTGCCACTAGCGGTTCC-3') were used (see Mattiucci et al., 2016). PCRs were carried out in a 25

$215 \mu$ l volume containing $0.5 \mu \mathrm{l}$ of each primer $10 \mathrm{mM}, 2.5 \mu \mathrm{l}$ of $\mathrm{MgCl}_{2} 25 \mathrm{mM}$ (Promega), $1.5 \mu \mathrm{l}$ of $5 \mathrm{x}$

216 buffer (Promega), DMSO 0.08 mM, $0.5 \mu \mathrm{l}$ of dNTPs $10 \mathrm{mM}$ (Promega), $5 \mathrm{U}$ of Go-Taq Polymerase

217 (Promega) and $2 \mu$ l of total DNA. PCR temperature conditions were as follows: $94{ }^{\circ} \mathrm{C}$ for 3 min (initial

218 denaturation), followed by $35 \mathrm{cycles}$ at $94^{\circ} \mathrm{C}$ for $45 \mathrm{sec}$ (denaturation), $58^{\circ} \mathrm{C}$ for $40 \mathrm{sec}$ (annealing),

$21972{ }^{\circ} \mathrm{C}$ for $1 \mathrm{~min}$ (extension) and followed by post-amplification at $72^{\circ} \mathrm{C}$ for $10 \mathrm{~min}$. An initial sample

220 of 50 individuals, belonging to the two species, $A$. pegreffii and A. simplex (s. s.), previously identified

221 by allozymes, were sequenced at the elongation factor 1 alpha 1 gene. The obtained sequences were

222 aligned in order to detect any fixed diagnostic nucleotide positions, which would allow to separate

223 the two species under examination (see Mattiucci et al., 2016).

Subsamples of Hysterothylacium spp. larvae or adults were identified to species level by sequence analysis of the internal transcribed spacers (ITS rDNA) region. PCR amplification was performed using the primers NC5 (5'-GTAGGTGAACCTGCGGAAGGATCATT-3') and NC2 (5'-TTAGTTTCTTTTCCTCCGCT$\left.3^{\prime}\right)$, as reported by Zhu et al. (2000). PCR amplification conditions were as follows: $94^{\circ} \mathrm{C}$ for $5 \mathrm{~min}$ (initial denaturation), followed by 30 cycles at $94^{\circ} \mathrm{C}$ for $30 \mathrm{sec}$ (denaturation), $55^{\circ} \mathrm{C}$ for $30 \mathrm{sec}$ (annealing), $72^{\circ} \mathrm{C}$ for $30 \mathrm{sec}$ (extension) and a final elongation step at $72^{\circ} \mathrm{C}$ for $5 \mathrm{~min}$ (Zhu et al., 2000). Obtained sequences were analyzed with GenBank Blast software and aligned with previously characterized sequences by applying ClustalX (Thompson et al., 1997). Phylogenetic analysis of the sequences obtained from specimens of the genera Anisakis, Pseudoterranova, Contracaecum and Hysterothylacium, was inferred with the Bayesian inference method and performed by using MrBayes (Ronquist et al., 2012) while Bayesian analysis was performed with Jmodeltest (Posada, 2008), using the Akaike Information Criterion (AIC) (Posada and Buckley, 2004). Posterior probabilities were estimated and used to assess support for each branch in inferred phylogeny with probabilities where $P \geq 95 \%$ was indicative of significant support (Reeder, 2003).

\subsection{Infection data analyses}

In order to account for the effect of fish size on estimates of Anisakis spp. prevalence and abundance, we fitted generalised additive models (GAM) to prevalence and abundance, for each species and each sampling area of the Atlantic and Mediterranean Sea. To avoid overfitting, the complexity of smoothers was restricted by setting a maximum value for bases dimension ( $k=4)$. For abundance data, negative binomial or Poisson models were fitted, the latter being appropriate only 
for area-species combinations with low maximum abundance $(<10)$; for higher maximum abundance levels, Poisson model diagnostics indicated overdispersion of the abundance data. For presenceabsence data, binomial models were fitted. In all cases, the default link functions were applied, i.e. log for Poisson and negative binomial models, and logit for binomial models. No models were fitted if sample size was $<20$, if prevalence was $<0.05$. Additionally, if prevalence was $100 \%$, no model was fitted. Regardless of whether the size effect was significant, models were used to predict Anisakis spp. presence or abundance (mean and SE) in fish of (a), mean size sampled for the species and (b), mean size sampled for the modelled species-area combination. All models were fitted in R. Note that standard error values are reported to indicate confidence in the mean value, but in the case of nonnormal distributions, confidence intervals must be calculated prior to back-transformation of results onto the response scale.

\section{Results and discussion}

259

The results focus mainly on occurrence and distribution of zoonotic anisakid species in the edible parts of fish, which for most species implies the flesh. However, some fish species such as sardine and anchovy, are commonly consumed round, i.e. uneviscerated, due to their small size, and often only lightly processed as in salting or marinating. This practice is common in Mediterranean countries and, although restaurants are obliged to freeze the fish prior to processing, many households prepare the dishes without prior thermal treatment (Cipriani et al., 2016). Therefore, in certain coastal regions in southern Europe, Anisakis spp. infections in the viscera of some fish species may represent a consumer health risk. However, for general assessment of the consumer exposure risk related to the presence of anisakid larvae in particularly relevant fish species or products thereof (see section 3.2.4. - Anisakis spp. exposure risk profile), three aspects were primarily considered here; 1) larval occurrence in the fish flesh and, whenever appropriate, their preferred infection site, 2) fish host body size/length, and, 3) differences in larval infection characteristics or species composition related to geographic area or fish stock. For fish or products processed mainly for the fresh fish markets, the preferred site of the larvae was recorded to assess the spatial distribution pattern as basis for advising the industry as to possible trimming of fillets in order to reduce the probability of parasite presence.

\subsection{Basic Anisakis spp. infection characteristics by fish host species}

\subsubsection{Atlantic mackerel (Scomber scombrus)}

278 Mackerel from off NW Spain and Portugal showed significantly higher prevalence, abundance and intensity of Anisakis sp. larvae compared to their North- and Norwegian Sea and Mediterranean 
congeners, both when considering overall infection (viscera and flesh) and infection in the flesh. The by far lowest infection levels were recorded in mackerel from the Mediterranean fishing grounds, with only around $4 \%$ larval prevalence in the fish flesh and a maximum intensity of one (1) larva. Regardless of fish host size or catching area, the largest proportions of muscle residing larvae occurred in the ventral sections of the fish flesh which for most fish species including Atlantic mackerel, comprises the belly flaps.

GAM-analyses revealed a highly significantly positive relationship between both prevalence and abundance of flesh residing Anisakis spp. larvae, and body size/length of mackerel from the North Sea (Fig. 4 a, d). However, the relationship tended to weaken with lower latitudes, e.g. the same variables were only very weakly related in mackerel caught off NW Spain and Portugal (Fig. 4 b, e). Moreover, no significant effect of host body length on larval prevalence and abundance in the flesh was apparently present in fish caught in the southern Norwegian Sea (Fig. 4 c, f) which represented the northernmost catching locality of Atlantic mackerel. Due to generally very low larval infection levels in the fish flesh, GAMs were not fitted for S. scombrus from any of the Mediterranean fishing grounds.

Genetic anisakid species identification revealed that $A$. simplex sensu stricto (s. s.) is the dominating species in mackerel from the Atlantic fishing areas. However, we recorded four A. pegreffii larvae in the viscera of three mackerel caught in the northernmost fishing areas, i.e. the North Sea and southern Norwegian Sea. Similarly, 11 A. pegreffii were identified in mackerel caught in the southern North Sea including the English Channel. In the waters off NW Spain and Portugal, A. simplex (s. s.) constitutes still the largest sibling fraction (86\%), with A. pegreffii and A. simplex (s. s.)/A. pegreffii F1 hybrids occurring at much lower frequencies ( $11 \%$ and $3 \%$, respectively). In the mackerel caught in the Mediterranean, A. pegreffii appears to be the dominating species with only three A. physeteris larvae detected in three individual mackerel. The findings imply that Anisakis sibling species may be useful supplementary biological markers to further elucidate changing migration patterns or intermixing between different spawning stocks of Atlantic mackerel (see Levsen et al., submitted).

\subsubsection{Chub mackerel (Scomber colias)}

Overall prevalence of anisakid larvae in chub mackerel collected in the Atlantic Ocean and Mediterranean Sea was $60.7 \%$ while overall mean intensity reached 15.3 . Although the infection differed greatly between fillets and viscera, both in terms of prevalence $(p<0.001)$ and mean intensity $(p<0.01), 18.1 \%$ prevalence and mean intensity of 2.1 in the flesh/fillets is important from a consumer's point of view. The anterio-ventral (AV) parts of the fillets were the preferred infection 
site in the flesh of chub mackerel, carrying between 67\% (Tyrrhenian Sea) and 100\% (Atlantic waters, ICES IXa) of all muscle residing Anisakis spp. larvae, respectively (Table 2).

Highest overall prevalence (100\%) and mean abundance $(145.9 \pm 84.5)$ was recorded in chub mackerel originating from the Central and southern Adriatic Sea. These findings illustrate the importance of fish host size as predictor of parasite occurrence in the Adriatic Sea since the chub mackerel were on average more than $12 \mathrm{~cm}$ longer than the other Adriatic samples. This trend was also apparent in the flesh of these fish where both prevalence (78.9\%) and mean abundance (3.8 \pm 2.9) were significantly higher compared to the other chub mackerel from the Adriatic Sea ( $n=325$; prevalence $21.2 \%$; abundance $0.33 \pm 0.81$ ). However, a highly significantly positive effect of fish host body size/length on larval prevalence and abundance in the fish flesh was still present in pooled samples of chub mackerel from all Adriatic localities ( $n=344$ ) (Fig. 5).

\subsubsection{Herring (Clupea harengus) (four stocks)}

The herring samples of the Norwegian spring spawning stock (NSS), which were obtained in the southern Norwegian Sea and around the Faroe Islands, showed significantly higher prevalence and abundance of $A$. simplex (s. s.) larvae compared to herring of the other stocks (Table 3 ). The differences were most pronounced for larvae residing in the fish flesh. Both prevalence and mean abundance of muscle residing larvae in herring of the NSS stock were more than twice as high, reaching $37.1 \%$ and 0.6 , respectively, compared to herring belonging to the North Sea- or western Baltic stock. However, the herring of the NSS stock were significantly larger ( $t$-test, $p<0.001)$ than their congeners of the other stocks. Indeed, there seems to be a marked accumulation effect of fish size on A. simplex (s. s.) abundance in NE Atlantic herring. Thus, in all stocks considered here, there was a markedly positive relationship between fish host size $(\mathrm{TL})$ and overall larval prevalence and abundance. The effect of fish host body length as major predictor of larval occurrence in the flesh of herring is illustrated in Fig. 6, exemplified by the present Norwegian spring spawning- and Baltic stock samples. The findings underline the importance of proper freezing, especially of large NE Atlantic herring, before consumption in a semi-raw state such as in pickled or salted herring. However, herring caught east of Bornholm Island (ICES division BAL25) turned out to be uninfected and were hence not included in the analysis. This finding indicates that the actual fish belong to a separate Baltic herring stock entity with another migration pattern which probably excludes southern or western areas of the Baltic Sea (e.g., BAL 24) where Anisakis spp. fish infections commonly occur. Additionally, there were no marked differences between the herring stocks with respect to relative larval distribution in the fish flesh, i.e., between $87 \%$ and $91 \%$ of the larvae occurred in the belly flaps, with almost equal proportions lodging in the left and right flesh side. 
351 Genetic anisakid species identification using diagnostic allozymes and sequence analysis of the 352 mtDNA-cox2 gene, revealed that the entire subsample of Anisakis ( $n=1395)$ collected from all herring 353 stocks considered here, belonged to A. simplex (s. s.). However, 481 Anisakis spp. larvae, collected 354 from herring sampled in the Norwegian-, Baltic- and North Sea including the English Channel, were 355 further analyzed with respect to intraspecific genetic differentiation within the populations from the 356 four sampling areas by applying mtDNA cox2 sequence analysis. Genetic differentiation at population level between the different fishing areas, was estimated and compared based on molecular variance analysis and $\mathrm{F}_{\mathrm{st}}$ values. Haplotype network construction showed significant differences in frequencies between samples of $A$. simplex (s. s.) from the actual areas. The results indicate a genetic substructuring of $A$. simplex (s. s.) from herring fished in different areas of the NE Atlantic, which again seems largely to correspond to the different herring stocks reported in the literature. Thus, the $A$. simplex (s. s.) population in herring from the Norwegian Sea appears to be the most differentiated one, whereas lowest level of genetic differentiation was observed between the North Sea and Baltic Sea populations. The results suggest that mtDNA $\operatorname{cox} 2$ is a suitable genetic marker for $A$. simplex (s. s.) population structure analysis, which may also prove useful in further investigations of the herring stock structure in the NE Atlantic Ocean (see Mattiucci et al., submitted).

\subsubsection{Sardine (Sardina pilchardus)}

Sardines from the Atlantic fishing ground (ICES IXa) showed comparatively high Anisakis spp. prevalence in both viscera (approximately 62\%) and in the flesh (17\%) which appears to be considerably higher than previously reported infection levels in sardine from this fishing area (see Rodríguez et al., submitted).

In sardines from the Mediterranean, one of the most important findings is the occurrence of $A$. pegreffii in almost $50 \%$ of the fish caught off West Sardinia (FAO 37.1.1), exceeding all other Mediterranean locations. This finding is apparently closely related to fish host body size since sardines from the latter locality were on average more than $20 \mathrm{~mm}$ larger than the rest of the sample (Table 4). In contrast, the smallest of the present sardines, sampled in the northern Tyrrhenian Sea (FAO 37.1.3), were apparently free from A. pegreffii larvae. The significantly positive effect of host body size/length as main predictor of larval infection in the flesh of sardine from the present Mediterranean localities, is illustrated in Fig. 7. Another important finding is the presence of larvae in sardine fillets which was observed for the first time in the present study. Furthermore, infection site proved to have a significant effect even after 
removing the variability in the abundance of $A$. pegreffii due to fish host size. Consequently, the risk for consumers arising from these findings is obvious since sardines are often subjected to inadequate thermal processing or evisceration due to small fish size prior to preparation of marinated or salted home-made sardines, traditionally eaten throughout the Mediterranean region. Nonetheless, even in cases of higher prevalence, mean intensity of infection in sardines was usually low, between 1 and 2 , both in fillets and viscera.

\subsubsection{Anchovy (Engraulis encrasicolus)}

There appears to be much higher Anisakis sp. prevalence and abundance in anchovies from central areas of the Adriatic Sea and off Galicia (Spain) which makes anchovy a food safety-related "hotspot" in parts of Spain and Italy. For the Atlantic samples, Anisakis spp. prevalence reached $83 \%$ and $29 \%$ in the viscera and flesh, respectively, in some batches (Rodríguez et al., this volume). Similar high infection levels were reported from the Central Adriatic Sea, with prevalences reaching $69.5 \%$ and $14.6 \%$ in the viscera and flesh, respectively (Cipriani et al. (a), this volume). Interestingly, while the effect of anchovy body size/length on larval prevalence in the flesh was comparatively weak in both localities, fish size/length was a highly significant predictor of larval abundance in either fishing area (Fig. 8). The former finding may imply, however, that other factors than fish size, e.g. generally high Anisakis sp. biomass due to abundantly occurring suitable crustacean and cetacean hosts, are important drivers of larval presence in anchovy from these areas, as well.

All larvae ( $N=547)$ obtained from anchovies caught in the Mediterranean Sea, correspond to $A$. pegreffii. The infection levels of $A$. pegreffii were significantly different between the present fishing areas of the Mediterranean Sea. Thus, fish from the Central and South Adriatic Sea showed highest prevalence and intensity, while anchovies from off southern Sicily and the Ionian- and Alboran Sea were apparently uninfected. The vast majority $(95.8 \%)$ of $A$. pegreffii larvae were located in the body cavity while only a smaller fraction (4.2\%) was present in the fish flesh. According to the present infection data for A. pegreffii in E. encrasicolus, the Central Adriatic Sea appears to be a "hotspot" for the presence of this parasite, showing infection levels which are by far higher than in any other area of the Mediterranean Sea. This finding could thus be related to ecological or oceanographic characteristics of this basin, including both abiotic and biotic factors which contribute to maintain the life cycle of $A$. pegreffii at high population size (Cipriani et al. (a), this volume).

\subsubsection{Atlantic cod (Gadus morhua)}

There were considerable differences in Anisakis spp. infection level in cod from different sampling areas, e.g. the prevalence varied between $16 \%$ in Baltic cod and $100 \%$ in cod from the Barents Sea. In 
general, Anisakis spp. prevalence and abundance, both in whole fish and in the fish flesh, correlated with fish length, and tended to increase with increasing fish size. Fishing area appeared to be a significant effector of Anisakis spp. infection in the fillets, with higher prevalence for fish sampled in the Barents Sea compared to the North Sea and the Baltic Sea. However, cod from the Baltic Sea were significantly smaller than the other fish sampled. It is useful to complete this analysis with a more detailed approach for the North Sea area. Two ICES subdivisions were sampled, the northern North Sea (IVa) and the Central North Sea (IVb). Even though these samples have been grouped for the statistical analysis (see Gay et al., this volume), the prevalence both in fillets and overall fish were statistically different for these two sub-areas $(p<0.05)$. The infection pattern in area IVa was similar to the pattern seen in cod from the Barents Sea compared to area IVb. In the flesh of cod, most larvae resided in the ventral portion of the fillets, which in cod corresponds largely to the belly flaps. In pooled samples covering all sampling areas, the prevalence of Anisakis spp. in the belly flaps was $39 \%$ while only $12 \%$ carried larvae in the dorsal part of the fillets.

Other zoonotic ascaridoid genera were also observed. Pseudoterranova was present in the flesh of $12 \%$ of the sampled fish, with a peak of prevalence of $27 \%$ for the northern North Sea sample. Hysterothylacium prevalence varied between 0\% for the Baltic Sea and $84 \%$ for the Barents Sea. The distribution of Contracaecum was also very variable, with no Contracaecum isolated from the fish from the Central North Sea and a prevalence of $100 \%$ for the commercial size cod sampled in the Baltic Sea.

\subsubsection{Haddock (Melanogrammus aeglefinus)}

Haddock were sampled around Scotland (East and West coasts) and in the Barents Sea. Average length was highest in the Barents Sea $(584 \mathrm{~mm})$ and higher on the East coast than on the West coast of Scotland ( $365 \mathrm{~mm}$ vs $311 \mathrm{~mm}$ ). This variation was statistically significant (Kruskal-Wallis test, $\mathrm{P}<0.001)$ and indeed there was almost no overlap in size between Scottish and Barents Sea fish. Prevalence and abundance of Anisakis sp. (genetic species identification was not performed) infection followed the same trend as average size: 50\% prevalence and average abundance 3.4 on the West coast of Scotland, compared to $84 \%$ and 14.5 on the East coast, and $100 \%$ and 50.5 in the Barents Sea. Highest Anisakis sp. intensity was 183 in a haddock from the Barents Sea. Prevalence and abundance of larvae increased with fish size in the present samples.

In Scottish fish, Anisakis sp. were present in $1 \%$ of fillets from West coast fish and $11 \%$ of fillets from East coast fish, prevalence in fillets was much higher in Barents Sea fish, at 73\%, although the mean number present was $<1$ and the maximum only 12 . 
456 Pseudoterranova sp., Hysterothylacium aduncum and Contracaecum sp. were all recorded, with 457 higher prevalence and abundance in Barents Sea fish. Of these, Contracaecum sp. was most 458 prevalent (36\%) but occurred at lowest abundance (mean 0.6, maximum 7), H. aduncum had the 459 highest abundance (mean 1.8, maximum 62) while Contracaecum sp. was not recorded in Scottish 460 fish but again $H$. aduncum was the most abundant of the three genera (mean 0.9 and maximum 13 in 461 East coast samples).

462

\subsubsection{European hake (Merluccius merluccius)}

464

Both prevalence and abundance of Anisakis spp. infection were very high in hake caught in the Grand Sole Bank area, the Cantabric Sea and off NW Spain and Portugal (ICES VIIj, VIIIc and IXa). Highest larval infection levels were found in fish from the Grand Sole Bank (ICES VIIj), with mean and maximum abundance in the flesh reaching 129 and 1484 larvae, respectively. These were the highest infection levels recorded in the present survey of the PARASITE project, regardless of fish host species or geographical sampling area. Due to the importance of hake for various European fresh fish markets, we consider such Anisakis spp. infection levels in the fish flesh as very high, which again calls for proper precautionary heat- or freezing treatment before consumption.

Mixed infections with A. simplex (s. s.) and A. pegreffii were recorded in subsamples of larvae ( $n=2806$ ) from M. merluccius caught off NW Spain and Portugal, with the majority (ca $70 \%$ ) genetically identified as $A$. simplex (s. s.) while approx. $30 \%$ belonged to $A$. pegreffii. The findings confirm that this particular fishing ground represents a marked sympatric area for both parasite species. GAM analysis revealed that Anisakis spp. prevalence and abundance in the flesh increased with host body size/length, exemplified in Fig. 9 (b) for effect on larval abundance in hake from the Grand Sole Bank, which showed $100 \%$ larval prevalence in the flesh. However, some variations of this general trend exist depending on Atlantic fishing area, which is addressed in more detail by Pascual et al. (this volume).

Generally, all samples obtained from the fishing grounds of the western Mediterranean Sea showed comprehensively lower infection levels when compared to the fish originating from the Adriatic/Ionian Sea area. Indeed, highest infection levels (total prevalence (100\%) and overall mean abundance $A=157.3$, ranging 4-866) were recorded in hake caught off the Italian coast of the southern Adriatic Sea. Moreover, fish from the latter area were significantly larger (mean length 416 $\mathrm{mm}$ ) compared to fish from other parts of the Adriatic Sea $(p<0.001)$. High infection levels have been recorded also in hake caught off the Italian coast of the central Adriatic Sea (prevalence $P=89.8 \%$ and 
mean abundance $A=98.9$ ), despite of the on average smaller size of the fish obtained from this area (Cipriani et al. (b), this volume). Thus, a significantly positive relationship exists between fish host size/length and Anisakis spp. prevalence and abundance in the flesh of hake in pooled samples ( $n=466)$ from the present Adriatic fishing localities (Fig. 9 a, c). This implies that fish host body size is the major driver of Anisakis spp. occurrence and infection level in hake from both Atlantic and Mediterranean fishing grounds.

Among the Anisakis spp. subsamples genetically identified from Mediterranean hake, close to 93\% corresponded to A. pegreffii, 1 larva to A. simplex (s. s.) and 62 to A. physeteris. While A. pegreffii occurred around the viscera and in the flesh of the hake, $A$. physeteris larvae were only found in the visceral cavity.

\subsubsection{Blue whiting (Micromesistius poutassou)}

Blue whiting from Rockall (ICES area VIb) showed high prevalence and abundance of Anisakis larvae, both with respect to overall infection and infection in the fish flesh. Larval muscle infection reached a mean abundance of more than 14 larvae at $>92 \%$ prevalence while the maximum larval intensity in the flesh was 147 worms. In contrast, blue whiting sampled in the other NE Atlantic fishing areas including waters around Scotland (ICES IVa and VIa) and the Faroe Islands (ICES Vb), and off Portugal and NW Spain (ICES VIII-IX), showed significantly lower infection rates, with larval prevalence and mean abundance in the fish flesh reaching $52 \%$ and 6.1, respectively (Table 5 ). The maximum intensity was 69 larvae, which implies that the infection rates in the latter samples must still be considered high. However, blue whiting from the Rockall area were significantly larger than those from the other Atlantic areas (t-test; $p<0.001$ ). For the Atlantic blue whiting samples in general, there was a significantly positive correlation between fish host size (TL and TW) and larval abundance, both in total and in the flesh (for TL: $R_{S}=0.54, p<0.001 ; R_{S}=0.60, p<0.001$, respectively). However, this trend weakened with lower latitudes, i.e. in the blue whiting samples from off NW Spain and Portugal, larval abundance was only very weakly and as for the flesh, negatively, correlated with fish host length $\left(R_{S}=0.12, p<0.02 ; R_{S}=-0.11, p<0.02\right.$, respectively). There were no differences between sampling years.

Blue whiting sampled in the Mediterranean showed generally much lower Anisakis larval infection levels compared to their congeners from the Atlantic fishing areas. However, blue whiting from the Adriatic Sea still reached comparatively high overall infection values, presenting a maximum intensity of 305 and 8 worms in overall and muscle infection, respectively, at $34 \%$ prevalence of larvae residing in the flesh. In contrast, fish from the Alboran Sea showed only low values of Anisakis, e.g. 
very low prevalence and abundance in the fish flesh ( $3 \%$ and 0.04 , respectively), with maximum intensity not exceeding two larvae (Table 5). Although blue whiting from the Adriatic Sea represented by far the smallest fish examined, they still carried significantly higher Anisakis burden than their congeners from the Alboran Sea (bootstrap t-test, $p<0.001$ ). In both these Mediterranean areas there were comparatively weak but still significantly positive correlations between overall larval abundance and fish host body size (for TL in the Adriatic and Alboran Sea samples, respectively: $\mathrm{RS}=0.47, \mathrm{p}<0.001 ; \mathrm{RS}=0.32, \mathrm{p}<0.007)$.

Genetic species identification revealed that the subsample of 124 Anisakis larvae from blue whiting caught in the Norwegian Sea and off the Faroe Islands consisted of $A$. simplex (s. s.). A subsample of 37 worms from off the Portuguese coast (ICES IX) showed a mixed infection with A. simplex (s. s.) (30 specimens) and A. pegreffii (7 specimens). The whole subsample of 134 worms from M. poutassou fished in the Adriatic Sea consisted entirely of $A$. pegreffii.

\subsubsection{Whiting (Merlangius merlangus)}

Whiting were sampled from trawling surveys on the East and West coasts of Scotland (ICES areas IV and $\mathrm{VI}$, respectively). Fish from the West coast were larger on average, mainly due to the presence of larger numbers of fish $<120 \mathrm{~mm}$ in length that were almost absent from West coast samples. Prevalence and abundance of Anisakis sp. (genetic species identification was not performed) were both higher in larger fish (Spearman's correlations, $p<0.001$ in both cases). Overall prevalence of Anisakis sp. was slightly (but non-significantly) higher on the West coast (50.4\% versus $42.6 \%$, , Chi square test, $\mathrm{P}=0.076$ ), although mean abundance was slightly (again non-significantly) higher in East coast fish (7.9 versus 6.4). Abundance of Anisakis sp. in the fillets was higher in the East coast samples (22.7\% versus $8.9 \%$, Chi-squared test, $\mathrm{P}<0.001)$, with high numbers present in fillets of larger East coast fish but not in larger West coast fish. Hysterothylacium was recorded in $12.0 \%$ of West coast fish and $19.9 \%$ of East coast fish while Pseudoterranova was present in $1.0 \%$ and $2.7 \%$ of fish, respectively.

\subsubsection{Plaice (Pleuronectes platessa) and four-spotted megrim (Lepiorhombus boscii)}

For pooled samples, i.e. all geographical areas included, four-spotted megrim displayed higher Anisakis spp. prevalence in overall fish, in fillets and in viscera (60.6; 30 and $51.9 \%$, respectively) than plaice (23.9; 0.7 and $23.7 \%$, respectively) (Table 6). Mean weight and length of all batches from both species were quite similar, so that the differences were likely not related to fish size. Thus, the differences could be due to geographical origins since both species were sampled in different ICES areas (North Sea, West of Scotland and English Channel for the plaice, and Bay of Biscay, Portuguese 
waters and Southwest of Ireland for the four-spotted megrim). In each species, geographical area induced significant differences. Highest prevalence (42.7\%) was observed in plaice sampled in the West of Scotland, while highest prevalence in four-spotted megrim was observed for fish sampled in the Southwest of Ireland (82.1\%). The highest intensities were observed in four-spotted megrim sampled in the southwest of Ireland, reaching maximum 80 larvae. In plaice, highest abundance was observed off West Scotland with values up to 28. Larval prevalence in the flesh of plaice was very low, with only 3 infected fish out of 464 sampled (0.7\%), whereas almost one third (30\%) of the fourspotted megrim carried Anisakis spp. larvae in the flesh. A subsample of 11 larvae isolated from plaice caught in the English Channel (ICES VIId) were molecularly identified and were all assigned to Anisakis simplex (s. s.).

\subsubsection{Monkfish and black-bellied angler (Lophius piscatorius and L. budegassa)}

The two Lophius species were sampled in relatively small numbers. Monkfish was obtained from Atlantic waters, ICES areas VII, VIII and IX, as well as from the Alboran Sea of the Mediterranean, while black-bellied angler was also sampled in the Balearic- and Adriatic Seas. Highest overall Anisakis spp. prevalence and abundances were seen in areas VII and VIIIc, respectively, apparently with a slight tendency of small monkfish to show higher larval abundances in the flesh. Anisakis spp. abundance (but not prevalence) generally increased with fish length and differences were observed between different sampling periods. A difference in Anisakis spp. prevalence was found between male and female L. budegassa, with a higher prevalence of worms in female fish. It is worth noticing that the samples of monkfish caught in the Alboran Sea showed mixed infections with three Anisakis species, i.e. A. simplex (s. s.), A. pegreffii and A. physeteris, identified by allozymes and mtDNA cox2 sequence analysis. The actual larvae occurred in syntopy in the viscera of the same individual fish host.

\subsubsection{Silver scabbardfish (Lepidopus caudatus) and European sea bass (Dicentrarchus labrax)} Silver scabbardfish were obtained from four sampling areas of the Mediterranean Sea (Tab. 1). All fish regardless of sampling area were infected with Anisakis spp. larvae, i.e. P=100\%. Scabbardfish caught off Malta's coast and from off southern Sicily showed significantly higher overall larval abundance levels ( $M A=239 \pm 141$ and $M A=193 \pm 118$, respectively) compared to the fish from the other sampling areas ( $M A=50 \pm 59$ in pooled samples) $(p<0.001)$. However, and more importantly, the larval abundance in the fish muscle did not differ significantly between the different sampling areas, showing $47 \%$ prevalence and $M A=2.2 \pm 4.0$ with intensity ranging $1-24$ in pooled fish samples. All genetically identified larvae from the former areas belonged to $A$. pegreffii. Identification of larvae from scabbard fish sampled in the Alboran- and Tyrrhenian Seas revealed that $A$. pegreffii was still 
the most abundant sibling species, however, a few $A$. physeteris larvae $(\mathrm{N}=25)$ were found in both areas, occurring in syntopy with $A$. pegreffii in the viscera of one individual fish host in either locality. Interestingly, in the fish batch originating from the Alboran Sea, a single scabbard fish had a mixed infection with A. simplex (s. s.) (1 larva), A. nascettii (1 larva), and A. ziphidarum (1 larva), along with a majority of larvae belonging to $A$. pegreffii.

Parasite data of European sea bass are scarce. Of 38 fish collected and examined during the present survey, only two medium-sized specimens weighing 480 and $500 \mathrm{~g}$, and fished in the central Tyrrhenian Sea, appeared to be infected with 12 and 1 anisakid larvae, respectively, all situated around the organs of the visceral cavity. Sequence analysis of the mtDNA cox2 gene enabled to identify the nematodes as Contracaecum rudolphii sp. A, which matures and reproduces in piscivorous birds (Mattiucci et al., 2008).

\subsection{Anisakis spp. exposure assessment considerations}

\subsubsection{Effect of fish sampling and storage procedures}

The different post-catch storage modes applied by the surveyors before inspecting the fish for parasites, may under some circumstances have facilitated post-mortem migration of Anisakis spp. larvae from their original site around the visceral organs into the flesh of the hosts. While this is unlikely to occur in fish that is deep-frozen or eviscerated shortly after catch, larval post-mortem migration may take place in cases where the fish is cool-stored for several hours during transport and before processing. Such storage conditions may have prevailed in at least some of the present Mediterranean samples of anchovy and sardine obtained from local fishermen. Larval muscle penetrating behavior may also be facilitated by the very short migration distance between the visceral organs and the flesh of small fish such as anchovy and sardine. Thus, temperature and storage time appear to be the most important variables determining the activation and motility of Anisakis larvae, as observed in experimental studies (Cipriani et al., 2016; Šimat et al., 2015). Although storage temperatures above $2{ }^{\circ} \mathrm{C}$ seem to be required to induce any post-mortem migration of $A$. pegreffii larvae in anchovy (Cipriani et al., 2016), higher storage temperatures over shorter periods may have been the case for some of the present anchovy and sardine samples from the Mediterranean Sea. Thus, the possibility exists that at least some of the larval findings in the flesh of both anchovy and sardine may have been inflicted by post-mortem migration. Nevertheless, coolstorage and sales of freshly caught, i.e. unfrozen, anchovy and sardine illustrates the importance of these fish species as vector of anisakiasis when prepared raw or only lightly processed in private households in actual regions of Italy and Croatia (Moschella et al., 2004; Mattiucci et al., 2011, 2013; Mladineo et al., 2016). 


\subsubsection{Effect of fish host}

632 Results from GAM analyses indicated that fish host body size is a major predictor of Anisakis spp.

633 occurrence in most fish species presently analyzed. Thus, there was a clear trend towards

634 significantly positive relationships between fish host body size/length and both prevalence and

635 abundance of Anisakis spp. larvae in the fish flesh, in most cases this trend was independent from

636 fishing locality. However, exceptions from this trend became apparent in Atlantic mackerel where

637 the host length effect on larval muscular infection was only very weakly positive or even absent in

638 the present southern- or northernmost fishing localities, respectively. These findings indicate that

639 any accumulation over time of Anisakis spp. larvae does not take place in Atlantic mackerel. On the

640 contrary, a trend towards the opposite pattern, i.e. larger mackerel are carrying fewer larvae, at least

641 in some of the present Atlantic localities, could indicate that larger specimens of the actual stocks or

642 entities are able to cope with the infections immunologically. These aspects of the Anisakis spp.

643 infection pattern in the present Atlantic mackerel samples are addressed and discussed in detail by

644 Levsen et al. (submitted, this volume). Besides mackerel, a less significant effect of host body size on

645 A. pegreffii prevalence was apparently present in anchovy from certain Atlantic and Mediterranean

646 fishing localities. Thus, other biotic or abiotic factors that are characteristics of the actual localities,

647 may be important drivers of the observed infection patterns, as well. For details on these aspects of

648 Anisakis spp. occurrence in anchovy from Atlantic and Mediterranean fishing grounds, see Rodríguez

649 et al. (this volume) and Cipriani et al. (a) (this volume), respectively.

650

651 In general, however, the effect of body size on infection rate seems to be strongly related to a life-

652 history switch in preferred food source, e.g. after ontogenetic transition from a planktivorous to a

653 mainly piscivorous feeding habit, which has been demonstrated for several fish species including

654 herring and Atlantic cod (Levsen and Lunestad, 2010; Mouritsen et al., 2010; Münster et al., 2015) to

655 greatly increase exposure to anisakid nematodes. This again may result in larval accumulation over

656 time since Anisakis spp. larvae may stay alive for extended periods or even over a given fish host's

657 lifetime (Smith, 1984). The observed distribution of anisakid larvae exhibited very high spatial and

658 temporal variability, even within host species. Highly skewed distribution patterns are characteristic

659 for many parasite species (e.g., Shaw and Dobson, 1995) and Anisakis species appear to be typical in

660 this respect.

661

662 In the present herring samples we observed a highly significant increase in overall Anisakis simplex (s.

663 s.) abundance with increasing fish size. The relationship was apparently independent of geographical 664 sampling locality. Similarly, the extremely high Anisakis spp. infection levels in both flesh and viscera 
of European hake from the Grand Sole area (ICES VII) strongly suggest that also this case relates most likely to fish host body size since hake from this particular fishing ground were by far the largest fish (both in terms of TL and TW) of all hake examined in the present survey (for details, see Pascual et al., submitted, this volume).

The possible presence of Anisakis spp. larvae in the fish flesh represents the greatest concern with respect to consumer exposure risk, especially in fish intended for consumption in a fresh state, i.e. without prior freezing. Thus, the present survey revealed that the vast majority of the flesh residing larvae are situated in the ventral portion of the fish muscle, which in most fish species corresponds to the belly flaps. Thus, trimming of the fillets by removing most of the belly flaps (herring, cod) would significantly reduce the probability of Anisakis larvae to be present in the final product. For example, Levsen and Lunestad (2010) found when investigating the Anisakis simplex (s. I.) occurrence in Norwegian spring spawning herring, that the probability of larval presence in trimmed herring fillets (by removing the belly-flaps) was 5 to 8 times lower compared to untrimmed fillets.

It is also apparent that, for all samples analyzed, larval mean abundances observed in the fish flesh were generally correlated with the number of worms found in the visceral cavity/organs: a global analysis of mean abundances for all samples gives Spearman's $r=0.84(p<0.001)$. However, an exception from this general trend was seen in Atlantic mackerel where several specimens, up to 5.2 $\%$ of each batch and sampling locality, carried Anisakis spp. larvae in the flesh only, i.e. the visceral cavity was not infected (see Levsen et al., submitted).

\subsubsection{Effect of fishing ground/oceanographic area}

The most conspicuous difference between the Atlantic- and Mediterranean fishing grounds with regards to general Anisakis spp. infection characteristics relates to the relative occurrence of Anisakis sibling species. Thus, A. simplex (s. s.) is the predominating species in the Atlantic samples of the present survey, while A. pegreffii dominates all samples from the Mediterranean Sea. However, there is considerable sympatric overlap between the western Mediterranean (Alboran Sea) and the Bay of Biscay in the Atlantic. Moreover, a few A. pegreffii were also found in Atlantic mackerel as far north as the Norwegian Sea. Since Atlantic mackerel, which spawn in deep water between the Mediterranean and the Faroe Islands, undertake extensive feeding migrations between the southern spawning- and the northern feeding grounds (Jansen and Gislason, 2013), the finding of A. pegreffii in mackerel collected in the Norwegian Sea strongly indicate that the fish became infected as juveniles in areas much further south such as the southern Bay of Biscay. Thus, A. pegreffii may prove a useful supplementary marker to further explore the northerly migration routes, especially of the 
700

701

702

703

704

705

706

707

708

709

710

711

712

713

714

715

716

717

718

719

720

721

722

723

724

725

726

727

728

729

730

731

732

733

southern and western spawning components of the Atlantic mackerel stock (see Levsen et al., submitted).

Additionally, small numbers of another Anisakis sibling species, A. physeteris, were found in a few specimens of Atlantic mackerel, silver scabbard fish, European hake and monkfish caught in the Mediterranean Sea. However, these records were very rare, and no worms were found in the flesh of the hosts. Therefore, A. physeteris is unlikely to pose any significant risk to human health in European waters. The same applies also for $A$. nascettii ( 1 larva) and $A$. ziphidarum (1 larva) which were recorded in the visceral cavity, along with several $A$. pegreffii and $A$. simplex (s. s.), in a single scabbard fish from the Alboran Sea.

Especially within the present Mediterranean sampling areas there seem to exist geographical "hotspots" of $A$. pegreffii infections in some fish species, which appear to relate more closely to oceanographic characteristics of the actual localities rather than specific fish host traits. For example, anchovy caught close to the Italian coast of the Central and South Adriatic Sea showed comprehensively higher A. pegreffii prevalence and abundance, both in the viscera and the flesh, than anchovy from all other sampling localities in the Mediterranean Sea. Interestingly, however, the anchovy from the Adriatic infection "hotspot" area were smaller (mean $\mathrm{TL}<130 \mathrm{~mm}$ ) than their congeners from the other Mediterranean fishing grounds, which were larger (mean TL $>130 \mathrm{~mm}$ ) but showed considerably lower A. pegreffii infection levels. This may indicate that specific oceanographic or ecological factors at the actual fishing area have greater effect on the $A$. pegreffii infection level than specific fish host characteristics such as body size/length.

Considering that E. encrasicolus has been reported as the main source of human cases of anisakiasis in certain regions of Italy (Moschella et al., 2004; Mattiucci et al., 2011, 2013) and Spain (Daschner et al., 2000), mostly after the consumption of raw homemade marinated anchovies, the present epidemiological data of $A$. pegreffii in the flesh of anchovy represent important data to evaluate the consumer exposure risk associated with the parasite. Thus, there could be a relation between the high A. pegreffii infection levels of anchovy from the Adriatic Sea and some clinical data on cases of anisakiasis in Italy. Interestingly, most cases of human anisakiasis in Italy were actually recorded in some regions which are in comparatively close vicinity to the coast of the Central Adriatic Sea (Mattiucci pers. observation).

\subsubsection{Anisakis spp. exposure risk profile}


734 In Fig. 10, we introduce a graphical Anisakis spp. exposure risk profile including seven (7) fish species 735 which we consider at highest risk to act as source of anisakiasis in Europe. All species covered in the 736 profile are more or less frequently consumed in a raw or only lightly processed state, without prior 737 freezing, or may be served under-cooked, i.e. if the heating treatment is inadequate, not reaching 60 $738{ }^{\circ} \mathrm{C}$ throughout the product. The present risk categories (from no risk to very high) are based on prevalence data of Anisakis spp. larvae in the flesh of the actual fish species. Additional information with regards to particular fishing locality or processing mode of products (e.g. whole or filleted; trimmed or untrimmed fillets) is provided whenever appropriate. It is important to note, however, that for some of the species included in the profile, e.g. Atl. mackerel, herring and cod, trimming of the fillets by removing the ventralmost parts of the belly flaps (see Fig. 3), would reduce the probability of larval presence in the final (fresh) product by more than $90 \%$.

\section{Acknowledgements}

747 The present work was financially supported by the European Union's $7^{\text {th }}$ Framework 748 Programme for Research, Technological Development and Demonstration, project Parasite 749 risk assessment with integrated tools in EU fish production value chains (PARASITE), Grant 750 Agreement (GA) no. 312068.

751

752

\section{References}

753 Bao, M., Pierce, G.J., Pascual, S., González-Muñoz, M.I., Mattiucci, S., Mladineo, I., Cipriani, P., 754 Bušelić, I., Strachan, N.J.C., 2017. Assessing the risk of an emerging zoonosis of worldwide concern: anisakiasis. Scientific Reports 7, Article number: 43699. doi:10.1038/srep43699 
Cipriani, P., Acerra, V., Bellisario, B., Sbaraglia, G.L., Cheleschi, R., Nascetti, G., Mattiucci, S., 2016. Larval migration of the zoonotic parasite Anisakis pegreffii (Nematoda: Anisakidae) in anchovy, Engraulis encrasicolus: Implications to seafood safety. Food Contr. 59, 148-157.

Cipriani, P., Sbaraglia, G. L., Palomba, M., Giulietti, L., Bellisario, B., Bušelić, I., Mladineo, I., Cheleschi, R., Nascetti, G., Mattiucci, S. (a). Anisakis pegreffii (Nematoda: Anisakidae) in the European anchovy Engraulis encrasicolus, from the Mediterranean Sea: fishing ground as a predictor of the parasite distribution. Fish. Res., this volume.

Cipriani, P., Sbaraglia, G.L., Paoletti, M., Giulietti, L., Bellisario, B., Palomba, M., Bušelić, I., Mladineo, I., Nascetti, G., Mattiucci, S. (b). The Mediterranean European hake, Merluccius merluccius: detecting drivers influencing the Anisakis spp. larvae distribution. Fish. Res., this volume.

European Commission (EC), 2016. Facts and figures on the Common Fisheries Policy. Basic statistical data, 2016 edition. (https://ec.europa.eu/fisheries/sites/fisheries/files/docs/body/pcp_en.pdf, retrieved on $4^{\text {th }}$ April 2017)

D’Amelio, S., Mathiopoulos, K.D., Brandonisio, O., Lucarelli, G., Doronzo, F., Paggi, L., 1999. Diagnosis of a case of gastric anisakidosis by PCR-based restrictionfragment length polymorphism analysis. Parassitologia 41, 591-593.

Daschner, A., Alonso-Gomez, A., Cabanas, R., Suarez-de-Parga, J., Lopez-Serrano, M., 2000. Gastroallergic anisakiasis: borderline between food allergy and parasitic disease-clinical and allergologic evaluation of 20 patients with confirmed acute parasitism by Anisakis simplex. J. Allergy Clin. Immunol. 105, 176-181.

Gay, M., Bao, M., MacKenzie, K., Pascual, S., Buchmann, K., Bourgau, O., Couvreur, C., Hastie, L.C., Levsen, A., Pierce, G.J. Prevalence, abundance and species diversity of ascaridoid nematode in Atlantic cod, Gadus morhua, are correlated with geographic area and fish size. Fish. Res., this volume. Gómez-Morales, M.A., Martinez Castro, C., Lalle, M., Fernandez, R., Pezzotti, P., Abollo, E., Pozio, E. UV-press method versus artificial digestion method to detect Anisakidae L3 in fish fillets: comparative study and suitability for the industry. Fish. Res., this volume. 
González, A.F, Rodríguez, H., Outeiriño, L., Vello, C., Larsson, C., Pascual, S. Architecture of a Biobanking platform for marine fish-borne zoonotic parasites: saving samples, data and money. Fish. Res., this volume. Jansen, T., Gislason, H., 2013. Population Structure of Atlantic Mackerel (Scomber scombrus). PLOS ONE 8(5), e64744.

Karl, H., Leinemann, M., 1993. A fast and quantitative detection method for nematodes in fish fillets and fishery products. Archiv Lebensmittelhyg. 44, 124-125.

Klapper, R., Kuhn, T., Münster, J., Levsen, A., Karl, H., Klimpel, S., 2015. Anisakid nematodes in beaked redfish (Sebastes mentella) from three fishing grounds in the North Atlantic, with special notes on distribution in the fish musculature. Vet. Parasitol. 207, 72-80.

Llarena-Reino, M., Piñeiro, C., Antonio, J., Outeriño, L., Vello, C., González, A.F., Pascual, S., 2013. Optimization of the pepsin digestion method for anisakids inspection in the fishing industry. Vet. Parasitol. 191, 276-83.

Levsen, A., Lunestad, B.T., 2010. Anisakis simplex third stage larvae in Norwegian spring spawning herring (Clupea harengus L.), with emphasis in larval distribution in the flesh. Vet. Parasitol. 171, 247253.

Levsen, A., Karl, H., 2014. Anisakis simplex (s.l.) in Grey gurnard (Eutrigla gurnardus) from the North Sea: Food safety considerations in relation to fishing ground and distribution in the flesh. Food Contr. $36,15-19$.

Levsen, A., Paoletti, M., Cipriani, P., Nascetti, G., Mattiucci, S., 2016. Species composition and infection dynamics of ascaridoid nematodes in Barents Sea capelin (Mallotus villosus) reflecting trophic position of fish host. Parasitol. Res. 115, 4281-4291. Levsen, A., Cipriani, P., Mattiucci, S., Gay, M., Hastie, L.C., MacKenzie, K., Pierce, G.J., Svanevik, C.S., Højgaard, D.P., Nascetti, G., González, A.F., Pascual, S. Anisakis species composition and infection characteristics in Atlantic mackerel, Scomber scombrus, from major European fishing grounds - reflecting changing fish host distribution and migration pattern. Fish. Res., submitted, this volume. Lim, H., Bong-Kwang, J., Cho, J., Yooyen, T., Shin, E.H., Chai, J.Y., 2015. Molecular diagnosis of cause of anisakiasis in humans, South Korea. Emerg. Infect. Dis. 21, 342-344.

Mattiucci, S., Nascetti, G., Cianchi, R., Paggi, L., Arduino, P., Margolis, L., Brattey, J., Webb, S.C., D’Amelio, S., Orecchia, P., Bullini, L., 1997. Genetic and ecological data on the Anisakis simplex complex, with the evidence for a new species (Nematoda, Ascaridoidea, Anisakidae). J. Parasitol. 83, 401-416.

Mattiucci, S., Nascetti, G., 2008. Advances and trends in the molecular systematics of anisakid nematodes, with implications for their evolutionary ecology and host-parasite coevolutionary processes. Adv. Parasitol. 66, 47-148. 

relationships among species of Contracaecum Railliet and Henry, 1912 and Phocascaris Host, 1932 (Nematoda: Anisakidae) from pinnipeds based on mitochondrial cox2 sequences, and congruence with allozyme data. Parasite 15, 408-419. Mattiucci, S., Paoletti, M., Borrini, F., Palumbo, M., Palmieri, R.M., Gomes, V., Casati, A., Nascetti, G., 2011. First molecular identification of the zoonotic parasite Anisakis pegreffii (Nematoda: Anisakidae) in a paraffin-embedded granuloma taken from a case of human intestinal anisakiasis in Italy. BMC Infect. Dis. 11, 82. Costa, A., Meucci, C., Calvaruso, V., Sorrentini, I., Palma, G., Bruschi, F. and Nascetti, G., 2013. Anisakiasis and gastroallergic reactions associated with Anisakis pegreffii infection, Italy. Emerg. Infect. Dis. 19, 496-499. Mattiucci, S., Cipriani, P., Webb, S.C., Paoletti, M., Marcer, F., Bellisario, B., Gibson, D.I., Nascetti, G., 2014. Genetic and morphological approaches distinguish the three sibling species of the Anisakis simplex species complex, with a species designation as Anisakis berlandi n. sp. for $A$. simplex sp. C

832 (Nematoda: Anisakidae). J. Parasitol. 100, 199-214.

833 Mattiucci, S., Cipriani, P., Paoletti, M., Nardi, V., Santoro, M., Bellisario, B., Nascetti, G., 2015.

834 Temporal stability of parasite distribution and genetic variability values of Contracaecum osculatum 835 sp. D and C. osculatum sp. E (Nematoda: Anisakidae) from fish of the Ross Sea (Antarctica). Int. J. 836 Parasitol., Parasites and Wildlife, 4, 356-367.

837 Mattiucci, S., Acerra, V., Paoletti, M., Cipriani, P., Levsen, A., Webb, S.C., Canestrelli, D., Nascetti, G., 838 2016. No more time to stay 'single' in the detection of Anisakis pegreffii, A. simplex (s. s.) and 839 hybridization events between them: a multi-marker nuclear genotyping approach. Parasitology 143, 840 998-1011.

841 Mattiucci, S., Cipriani, P., Paoletti, M., Levsen, A., Nascetti, G., 2017. Reviewing biodiversity and 842 epidemiological aspects of anisakid nematodes from the North East Atlantic Ocean. J. Helminthol., 843 doi:10.1017/S0022149X1700027X.

844 Mattiucci, S., Giulietti, L., Paoletti, M., Cipriani, P., Gay, M., Levsen, A., Klapper, R., Karl, H., Bao, M., 845 Pierce, G.J., Nascetti, G. Population genetic structure of the parasite Anisakis simplex (s. s.)

846 (Nematoda: Anisakidae) in North East Atlantic herring stocks. Fish. Res., this volume.

847 Moschella, C.M, Mattiucci, S., Mingazzini, P., De Angelis, G., Assenza, M., Lombardo, F., Monaco, S., 848 Paggi, L., Modini, C., 2004. Intestinal anisakiasis in Italy: case report. J. Helminthol. 78, 271-273. 849 Mladineo, I., Poljak, V., 2014. Ecology and Genetic Structure of Zoonotic Anisakis spp. from Adriatic 850 Commercial Fish Species. Appl. Environ. Microbiol. 80, 1281-1290. 
Mladineo, I., Popovic, M., Drmic-Hofman, I., Poljak, V., 2016. A case report of Anisakis pegreffii (Nematoda, Anisakidae) identified from archival paraffin sections of a Croatian patient. BMC Infect. Dis. 16, 42.

Mouritsen, K.N., Hedeholm, R., Schack, H.B., Nukaaraq Møller, L., Storr-Paulsen, M., Dzido, J., Rokicki, J., 2010. Occurrence of anisakid nematodes in Atlantic cod (Gadus morhua) and Greenland cod (Gadus ogac), West Greenland. Acta Parasitol. 55, 81-89.

Münster, J., Klimpel, S., Fock, H.O., MacKenzie, K., Kuhn, T., 2015. Parasites as biological tags to track an ontogenetic shift in the feeding behaviour of Gadus morhua off West and East Greenland. Parasitol. Res. 114, 2723-2733 Pascual, S., Rodriguez, H., Pierce, G., Hastie, L., Gonzalez, A.F. The NE Atlantic hake: a careless high exposure risk for zoonotic parasites in European fish markets. Fish. Res., submitted.

Pippy, J.H., 1970. Use of ultraviolet light to find parasitic nematodes in situ. J. Fish. Res. Bd. Can. 27, 963-965.

Posada, D., 2008. JModelTest: Phylogenetic Model Averaging. Mol. Biol. Evol. 25, 1253-1256 Posada, D., Buckley, T.R., 2004. Model selection and model averaging in phylogenetics. Advantage of the AIC and Bayesian approaches over likelihood ratio test. Syst. Biol. 53, 793-808.

Reeder, T.W., 2003. A phylogeny of the Australian Sphenomorphus group (Scincidae : Squamata) and the phylogenetic placement of the crocodile skinks (Tribolonotus): Bayesian approaches to assessing congruence and obtaining confidence in maximum likelihood inferred relationships. Mol. Phylogen. Evol. 27, 384-397.

Rodriguez, H., González, A.F., Abollo, E., Pascual, S. Reevaluation of Atlantic anchovies (Engraulis encrasicolus) as a main risk factor for sensitization to zoonotic nematodes in Spain. Fish. Res., this volume.

Ronquist, F., Teslenko, M., van der Mark, P., Ayres, D. L., Darling, A., Hohna, S., Larget, B., Liu, L., Suchard, M.A., Huelsenbeck, J.P., 2012. MrBayes 3.2: Efficient bayesian phylogenetic inference and model choice across a large model space. Syst. Biol. 61, 539-542.

Shaw, D.J., Dobson, A.P., 1995. Patterns of macroparasite abundance and aggregation in wildlife populations: a quantitative review. Parasitology 111, S111-S133.

Šimat, V., Miletić, J., Bogdanović, T., Poljak, V., Mladineo, I., 2015. Role of biogenic amines in the post-mortem migration of Anisakis pegreffii (Nematoda: Anisakidae Dujardin, 1845) larvae into fish fillets. Int. J. Food Microbiol. 214, 179-186.

Smith, J.W., 1984. The abundance of Anisakis simplex L3 in the body cavity and flesh of marine teleosts. Int. J. Parasitol. 14, 491-495. 
884 Thompson, J.D., Gibson, T.J., Plewniak, F., Jeanmougin, F., Higgins, D.G., 1997. The CLUSTAL_X

885 windows interface: flexible strategies for multiple sequence alignment aided by quality analysis tools.

886 Nucl. Acid Res. 25, 4876-4882.

887 Timi, J.T., Paoletti, M., Cimmaruta, R., Lanfranchi, A.L., Alarcos, A.J., Garbin, L., George-Nascimento,

888 M., Rodríguez, D.H., Giardino, G.V., Mattiucci, S., 2014. Molecular identification, morphological

889 characterization and new insights into the ecology of larval Pseudoterranova cattani in fishes from

890 the Argentine Coast with its differentiation from the Antarctic species, P. decipiens sp. E (Nematoda:

891 Anisakidae). Vet. Parasitol. 199, 59-72.

892 Umehara, A., Kawakami, Y., Araki, J., Uchida, A., 2007. Molecular identification ofthe etiological agent

893 of the human anisakiasis in Japan. Parasitol. Int. 56, 211-215.

894 Zorica, B., Čikeš Keč, V., Vidjak, O., Mladineo, I., Ezgeta Balić, D., 2016. Feeding habits and helminth

895 parasites of sardine (S. pilchardus) and anchovy (E. encrasicolus) in the Adriatic Sea. Mediterran. Mar.

896 Sci. 17, 216-229.

897 Zhu, X.Q., D’Amelio, S., Paggi, L., Gasser, R.B., 2000. Assessing sequence variation in the internal

898 transcribed spacer of ribosomal DNA within and among members of the Contracaecum osculatum

899 complex (Nematoda: Ascaridoidea: Anisakidae). Parasitol. Res. 86, 677-683. 
Tab.1: Fish host species and sample size, along with number of Anisakis spp. subsamples for genetic species analysis, by fishing ground given as ICES/FAO fishing zones and name of sampling locality.

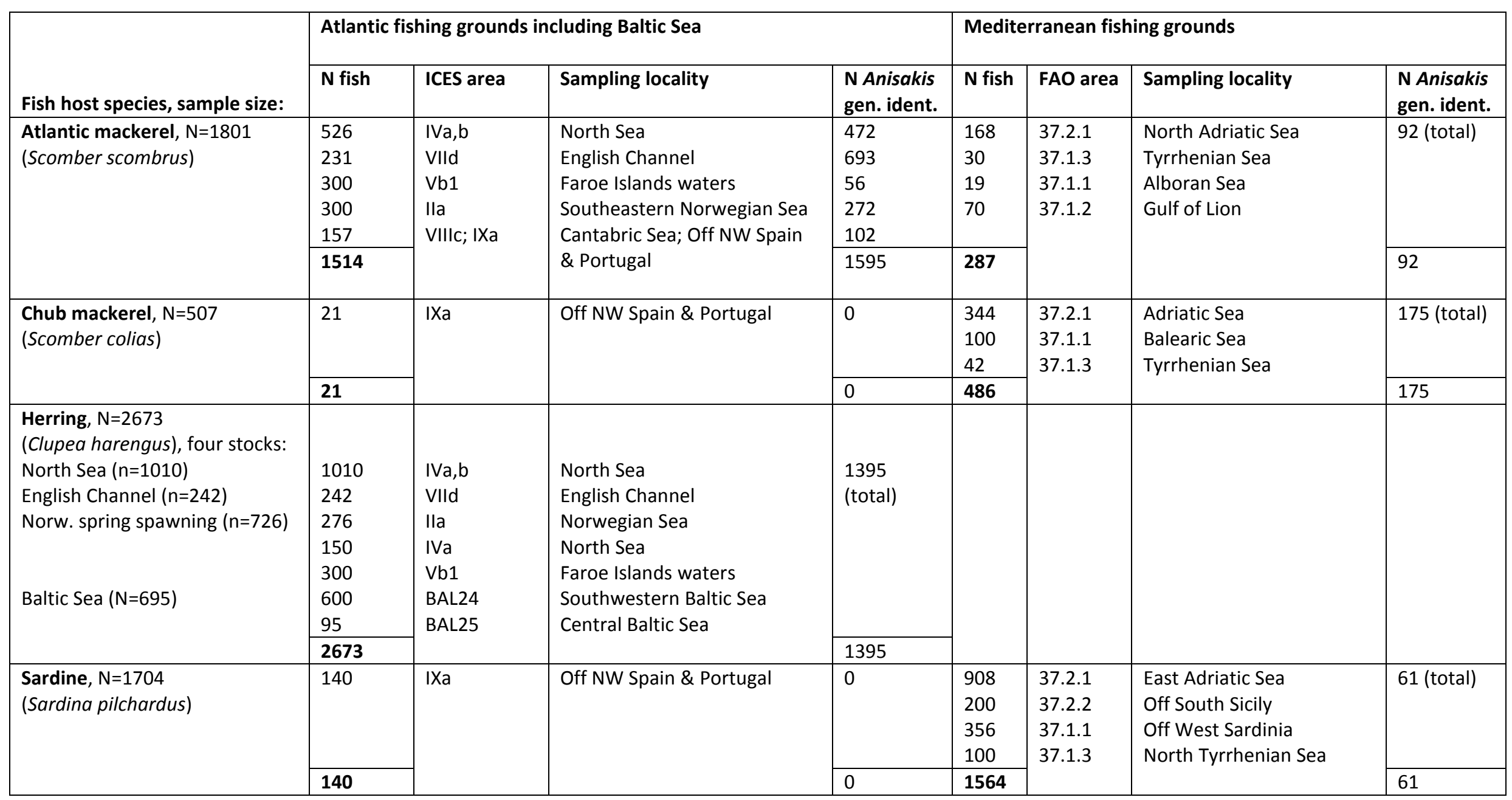




\begin{tabular}{|c|c|c|c|c|c|c|c|c|}
\hline \multirow[t]{2}{*}{$\begin{array}{l}\text { Anchovy, } \mathrm{N}=5108 \\
\text { (Engraulis encrasicolus) }\end{array}$} & 956 & VIIIC & Cantabric Sea & 0 & $\begin{array}{l}645 \\
528 \\
518 \\
280 \\
108 \\
200 \\
1323 \\
550\end{array}$ & \multirow[t]{2}{*}{$\begin{array}{l}37.2 .1 \\
37.2 .1 \\
37.2 .1 \\
37.2 .2 \\
37.3 .1 \\
37.2 .2 \\
37.1 .3 \\
37.1 .1\end{array}$} & \multirow[t]{2}{*}{$\begin{array}{l}\text { North Adriatic Sea } \\
\text { Central Adriatic Sea } \\
\text { East Adriatic Sea } \\
\text { South Adriatic-Ionian Sea } \\
\text { Aegean Sea } \\
\text { Off South Sicily } \\
\text { Tyrrhenian-Ligurian Sea } \\
\text { Sardinian-Balearic- } \\
\text { Alboran Sea }\end{array}$} & 547 (total) \\
\hline & 956 & & & 0 & 4152 & & & 547 \\
\hline \multirow[t]{2}{*}{$\begin{array}{l}\text { Atlantic cod (Gadus morhua), } \\
\mathrm{N}=755 \text { (incl. } 234 \text { cod of which } \\
\text { only the flesh was examined) }\end{array}$} & $\begin{array}{l}146(46) \\
386(188) \\
130 \\
93\end{array}$ & \multirow[t]{2}{*}{$\begin{array}{l}\text { I } \\
\text { BAL24, } 25 \\
\text { IVa } \\
\text { IVb }\end{array}$} & \multirow[t]{2}{*}{$\begin{array}{l}\text { Southern Barents Sea } \\
\text { Baltic Sea } \\
\text { Northern North Sea } \\
\text { Central North Sea }\end{array}$} & $\begin{array}{l}0 \\
76 \\
1913 \\
0 \\
\end{array}$ & & & & \\
\hline & $755(234)$ & & & 1989 & & & & \\
\hline \multirow[t]{2}{*}{$\begin{array}{l}\text { Haddock, } \mathrm{N}=441 \\
\text { (Melanogrammus aeglefinus) }\end{array}$} & $\begin{array}{l}150 \\
291\end{array}$ & \multirow[t]{2}{*}{ IVa,b; Vla } & \multirow[t]{2}{*}{$\begin{array}{l}\text { Southern Barents Sea } \\
\text { North Sea; Off West Scotland }\end{array}$} & $\begin{array}{l}0 \\
0\end{array}$ & & & & \\
\hline & 441 & & & 0 & & & & \\
\hline \multirow[t]{2}{*}{$\begin{array}{l}\text { European hake, } \mathrm{N}=1634 \\
\text { (Merluccius merluccius) }\end{array}$} & $\begin{array}{l}75 \\
188 \\
242\end{array}$ & \multirow[t]{2}{*}{$\begin{array}{l}\text { IVb; VIa } \\
\text { VII } \\
\text { VIIIc; IXa }\end{array}$} & \multirow[t]{2}{*}{$\begin{array}{l}\text { North Sea; Off West Scotland } \\
\text { Grand Sole } \\
\text { Cantabric Sea; Off NW Spain } \\
\text { \& Portugal }\end{array}$} & 388 (total) & $\begin{array}{l}72 \\
137 \\
257 \\
96 \\
27 \\
64 \\
241 \\
34 \\
49 \\
152 \\
\end{array}$ & \multirow[t]{2}{*}{$\begin{array}{l}37.2 .1 \\
37.2 .1 \\
37.2 .1 \\
37.2 .2 \\
37.3 .1 \\
37.2 .2 \\
37.1 .3 \\
37.1 .1 \\
37.1 .2 \\
37.1 .1\end{array}$} & \multirow[t]{2}{*}{$\begin{array}{l}\text { North Adriatic Sea } \\
\text { West Adriatic Sea } \\
\text { East Adriatic Sea } \\
\text { South Adriatic-Ionian Sea } \\
\text { Aegean Sea } \\
\text { Off South Sicily } \\
\text { Tyrrhenian-Ligurian Sea } \\
\text { Off West Sardinia } \\
\text { Gulf of Lion } \\
\text { Balearic-Alboran Sea }\end{array}$} & 877 (total) \\
\hline & 505 & & & 388 & 1129 & & & 877 \\
\hline \multirow[t]{2}{*}{$\begin{array}{l}\text { Blue whiting, } \mathrm{N}=1534 \\
\text { (Micromesistius poutassou) }\end{array}$} & $\begin{array}{l}453 \\
454 \\
133 \\
253\end{array}$ & \multirow[t]{2}{*}{$\begin{array}{l}\text { IVa; Vla; Vb } \\
\text { Vla,b } \\
\text { VIIIc } \\
\text { IXa }\end{array}$} & \multirow[t]{2}{*}{$\begin{array}{l}\text { North Sea incl. Faroe waters } \\
\text { Rockall } \\
\text { Cantabric Sea } \\
\text { Off NW Spain \& Portugal }\end{array}$} & $\begin{array}{l}124 \\
0 \\
0 \\
37\end{array}$ & $\begin{array}{l}172 \\
69\end{array}$ & \multirow[t]{2}{*}{$\begin{array}{l}37.2 .1 \\
37.1 .1\end{array}$} & \multirow[t]{2}{*}{$\begin{array}{l}\text { East Adriatic Sea } \\
\text { Alboran Sea }\end{array}$} & 134 \\
\hline & 1293 & & & 161 & 241 & & & 134 \\
\hline \multirow[t]{2}{*}{$\begin{array}{l}\text { Whiting, } \mathrm{N}=517 \\
\text { (Merlangius merlangus) }\end{array}$} & $\begin{array}{l}291 \\
226\end{array}$ & \multirow[t]{2}{*}{$\begin{array}{l}\text { IVa; IVb } \\
\text { Vla }\end{array}$} & \multirow[t]{2}{*}{$\begin{array}{l}\text { North Sea } \\
\text { Off West Scotland }\end{array}$} & $\begin{array}{l}0 \\
0\end{array}$ & & & & \\
\hline & 517 & & & 0 & & & & \\
\hline
\end{tabular}




\begin{tabular}{|c|c|c|c|c|c|c|c|c|}
\hline \multirow[t]{2}{*}{$\begin{array}{l}\text { Plaice, } \mathrm{N}=464 \\
\text { (Pleuronectes platessa) }\end{array}$} & $\begin{array}{l}240 \\
12 \\
102 \\
110\end{array}$ & \multirow[t]{2}{*}{$\begin{array}{l}\text { VIId, IVc } \\
\text { IVa } \\
\text { IVb } \\
\text { Vla }\end{array}$} & \multirow[t]{2}{*}{$\begin{array}{l}\text { English channel / S North Sea } \\
\text { Northern North Sea } \\
\text { Central North Sea } \\
\text { Off West Scotland }\end{array}$} & $\begin{array}{l}2 \\
9 \\
0 \\
0\end{array}$ & & & & \\
\hline & 464 & & & 11 & & & & \\
\hline \multirow[t]{2}{*}{$\begin{array}{l}\text { Four-spotted Megrim, N=287 } \\
\text { (Lepidorhombus boscii) }\end{array}$} & $\begin{array}{l}48 \\
139 \\
100\end{array}$ & \multirow[t]{2}{*}{$\begin{array}{l}\text { IXa } \\
\text { VIIj,k } \\
\text { VIIIC }\end{array}$} & \multirow[t]{2}{*}{$\begin{array}{l}\text { Off NW Spain \& Portugal } \\
\text { Grand Sole } \\
\text { Cantabric Sea }\end{array}$} & $\begin{array}{l}0 \\
0 \\
0\end{array}$ & & & & \\
\hline & 287 & & & 0 & & & & \\
\hline \multirow[t]{2}{*}{$\begin{array}{l}\text { Monkfish (Lophius spp.), } \mathrm{N}=211 \\
\text { L. piscatorius, } \mathrm{n}=64\end{array}$} & $\begin{array}{l}58 \\
83\end{array}$ & \multirow[t]{2}{*}{$\begin{array}{l}\text { VIIj,k; VIIIc; } \\
\text { IXa } \\
\text { VIIj,k; VIIIc; } \\
\text { IXa }\end{array}$} & \multirow[t]{2}{*}{$\begin{array}{l}\text { Grand Sole; Cantabric Sea; Off } \\
\text { NW Spain \& Portugal } \\
\text { Grand Sole; Cantabric Sea; Off } \\
\text { NW Spain \& Portugal }\end{array}$} & 157 (total) & $\begin{array}{l}6 \\
29 \\
30 \\
5\end{array}$ & \multirow[t]{2}{*}{$\begin{array}{l}37.1 .1 \\
37.1 .1 \\
37.1 .1 \\
37.2 .1\end{array}$} & \multirow[t]{2}{*}{$\begin{array}{l}\text { Alboran Sea } \\
\text { Alboran Sea } \\
\text { Balearic Sea } \\
\text { Adriatic Sea }\end{array}$} & 44 (total) \\
\hline & 141 & & & 157 & 70 & & & 44 \\
\hline \multirow[t]{2}{*}{$\begin{array}{l}\text { Silver Scabbardfish, } \mathrm{N}=86 \\
\text { (Lepidopus caudatus) }\end{array}$} & & & & & $\begin{array}{l}35 \\
29 \\
22\end{array}$ & \multirow[t]{2}{*}{$\begin{array}{l}37.2 .1 \\
37.1 .3 \\
37.2 .2\end{array}$} & \multirow[t]{2}{*}{$\begin{array}{l}\text { Alboran Sea } \\
\text { Tyrrhenian Sea } \\
\text { Off South Sicily and Malta }\end{array}$} & 398 (total) \\
\hline & & & & & 86 & & & 398 \\
\hline \multirow[t]{2}{*}{$\begin{array}{l}\text { European sea bass, } \mathrm{N}=38 \\
\text { (Dicentrarchus labrax) }\end{array}$} & & & & & $\begin{array}{l}17 \\
8 \\
13\end{array}$ & \multirow[t]{2}{*}{$\begin{array}{l}37.1 .1 \\
37.1 .3 \\
37.2 .1\end{array}$} & \multirow[t]{2}{*}{$\begin{array}{l}\text { Balearic Sea } \\
\text { Tyrrhenian Sea } \\
\text { Adriatic Sea }\end{array}$} & 3 (total) \\
\hline & & & & & 38 & & & 3 \\
\hline Total, $\mathrm{N}=17,760$ & 9707 & & & 5696 & 8053 & & & 2331 \\
\hline
\end{tabular}


Table 2. Sample size and basic fish host biometric data, along with basic Anisakis spp. infection parameters of chub mackerel (Scomber colias) from the Mediterranean Sea and Atlantic Ocean.

\begin{tabular}{|c|c|c|c|c|c|c|c|c|c|}
\hline \multirow[t]{2}{*}{ Fishing area } & \multirow[t]{2}{*}{$\mathrm{N}$ fish } & \multirow[t]{2}{*}{$\mathrm{TL}$} & \multirow[t]{2}{*}{ TW } & \multicolumn{4}{|c|}{ Musculature } & \multicolumn{2}{|c|}{ Viscera } \\
\hline & & & & $\mathrm{P}(\%)$ & Abund. / Intensity & $\begin{array}{l}\text { Rel. distr. } \\
\text { Vtrl : Drsl }\end{array}$ & $\begin{array}{l}\text { Rel. distr. } \\
\text { Left : Right }\end{array}$ & $\mathrm{P}(\%)$ & Abund. / Intensity \\
\hline $\begin{array}{l}\text { Adriatic Sea } \\
\text { (FAO 37.2.1 and 37.2.2) }\end{array}$ & 344 & $\begin{array}{l}220 \pm 46 \\
(105-400)\end{array}$ & $\begin{array}{l}81 \pm 35 \\
(8-397)\end{array}$ & 24.4 & $\begin{array}{l}\text { A: } 0.5 \pm 1.3(0-9) \\
\text { I: } 2.2 \pm 1.9(1-9)\end{array}$ & $85: 15$ & $53: 47$ & 73.8 & $\begin{array}{l}\text { A: } 12.4 \pm 39.2(0-326) \\
\text { I: } 16.8 \pm 44.9(1-326)\end{array}$ \\
\hline $\begin{array}{l}\text { Tyrrhenian Sea } \\
\text { (FAO 37.1.3) }\end{array}$ & 42 & $\begin{array}{l}333 \pm 23 \\
(280-390)\end{array}$ & $\begin{array}{l}352 \pm 78 \\
(200-589)\end{array}$ & 7.1 & $\begin{array}{l}\text { A: } 0.1 \pm 0.3(0-1) \\
\text { I: } 1.0(1)\end{array}$ & $67: 33$ & $100: 0$ & 54.8 & $\begin{array}{l}\text { A: } 2.7 \pm 2.6(0-10) \\
\text { I: } 3.7 \pm 2.3(1-10)\end{array}$ \\
\hline $\begin{array}{l}\text { Balearic Sea } \\
\text { (FAO 37.1.1) }\end{array}$ & 100 & $\begin{array}{l}285 \pm 20 \\
(250-350)\end{array}$ & $\begin{array}{l}206 \pm 45 \\
(130-357)\end{array}$ & 0 & / & I & / & 9.0 & $\begin{array}{l}\text { A: } 0.1 \pm 0.5(0-3) \\
\text { I: } 1.6 \pm 0.7(1-3)\end{array}$ \\
\hline $\begin{array}{l}\text { Atlantic Ocean } \\
\text { (ICES IXa) }\end{array}$ & 21 & $\begin{array}{l}286 \pm 27 \\
(250-335)\end{array}$ & $\begin{array}{l}207 \pm 55 \\
(141-309)\end{array}$ & 23.8 & $\begin{array}{l}\text { A: } 0.4 \pm 0.8(0-2) \\
\text { I: } 1.8 \pm 0.5(1-2)\end{array}$ & $100: 0$ & $56: 44$ & 61.9 & $\begin{array}{l}\text { A: } 5.8 \pm 8.0(0-26) \\
\text { I: } 9.4 \pm 8.3(1-26)\end{array}$ \\
\hline
\end{tabular}

Abbreviations: TL - Total body length $(\mathrm{mm})$; TW - Total body weight (g); P - prevalence, A - Abundance, I - Intensity, both given as mean \pm SD (range); Rel. distr. -

Relative distribution (\%); Vtrl - ventral portion of fish flesh (corresponds roughly to belly flap); Drsl - dorsal portion of fish flesh 
Table 3. Sample size and basic fish host biometric data, along with basic $A$. simplex (s. s.) infection parameters of herring (Clupea harengus) of four NE Atlantic stocks.

\begin{tabular}{|c|c|c|c|c|c|c|c|c|c|}
\hline \multirow{2}{*}{$\begin{array}{l}\text { Herring } \\
\text { stock }\end{array}$} & \multirow[t]{2}{*}{$\mathrm{N}$ fish } & \multirow[t]{2}{*}{ TL } & \multirow[t]{2}{*}{ TW } & \multicolumn{4}{|c|}{ Musculature } & \multicolumn{2}{|c|}{ Viscera } \\
\hline & & & & $P(\%)$ & $\begin{array}{l}\text { Abundance / } \\
\text { Intensity }\end{array}$ & $\begin{array}{l}\text { Rel. distr. } \\
\text { Vtrl : Drsl }\end{array}$ & $\begin{array}{l}\text { Rel. distr. } \\
\text { Left : Right }\end{array}$ & $\mathrm{P}(\%)$ & $\begin{array}{l}\text { Abundance / } \\
\text { Intensity }\end{array}$ \\
\hline North Sea & 1252 & $\begin{array}{l}273 \pm 28 \\
(149-358)\end{array}$ & $\begin{array}{l}171 \pm 55 \\
(40-435)\end{array}$ & 17.4 & $\begin{array}{l}\text { A: } 0.3 \pm 0.7(0-5) \\
\text { I: } 1.6 \pm 0.9(1-5)\end{array}$ & $89: 11$ & $50: 50$ & 81.2 & $\begin{array}{l}\text { A: } 11.2 \pm 17.0(0-176) \\
\text { I: } 13.7 \pm 17.6(1-176)\end{array}$ \\
\hline $\begin{array}{l}\text { Norw. spring } \\
\text { spawning }\end{array}$ & 726 & $\begin{array}{l}334 \pm 27 \\
(275-405)\end{array}$ & $\begin{array}{l}317 \pm 70 \\
(153-509)\end{array}$ & 37.1 & $\begin{array}{l}\text { A: } 0.6 \pm 1.0(0-8) \\
\text { I: } 1.6 \pm 1.1(1-8)\end{array}$ & $91: 9$ & $51: 49$ & 92.6 & $\begin{array}{l}\text { A: } 11.2 \pm 12.6(0-112) \\
\text { I: } 12.1 \pm 12.7(1-112)\end{array}$ \\
\hline $\begin{array}{l}\text { Baltic } \\
\text { - Western } \\
\text { - Central }\end{array}$ & $\begin{array}{l}695 \\
-600 \\
-95\end{array}$ & $\begin{array}{l}261 \pm 29 \\
(168-305) \\
216 \pm 10\end{array}$ & $\begin{array}{l}153 \pm 50 \\
(31-268) \\
106 \pm 9\end{array}$ & $\begin{array}{l}14.8 \\
0\end{array}$ & $\begin{array}{l}\text { A: } 0.2 \pm 0.5(0-3) \\
\text { I: } 1.3 \pm 0.5(1-3) \\
\text { Negative }\end{array}$ & $\begin{array}{l}87: 13 \\
\text { Negative }\end{array}$ & $\begin{array}{l}54: 46 \\
\text { Negative }\end{array}$ & $\begin{array}{l}65.5 \\
0\end{array}$ & $\begin{array}{l}\text { A: } 4.2 \pm 6.5(0-45) \\
\text { I: } 6.4 \pm 7.1(1-45) \\
\text { Negative }\end{array}$ \\
\hline & & $(189-240)$ & $(90-126)$ & & & & & & \\
\hline
\end{tabular}

Abbreviations: TL - Total body length (mm); TW - Total body weight (g); P - Prevalence; A - Abundance, I - Intensity, both given as mean \pm SD (range); Rel. distr. - Relative distribution (\%); Vtrl - ventral portion of fish flesh (corresponds roughly to belly flap); Drsl - dorsal portion of fish flesh 
Table 4. Sample size and basic fish host biometric data, along with basic Anisakis pegreffii infection parameters of sardine (Sardina pilchardus) from four Mediterranean sampling localities.

\begin{tabular}{|c|c|c|c|c|c|c|c|c|c|}
\hline \multirow[t]{2}{*}{ Fishing area } & \multirow[t]{2}{*}{$\mathrm{N}$ fish } & \multirow[t]{2}{*}{ TL } & \multirow[t]{2}{*}{ TW } & \multicolumn{4}{|c|}{ Musculature } & \multicolumn{2}{|c|}{ Viscera } \\
\hline & & & & $\mathrm{P}(\%)$ & Abund. / Intensity & $\begin{array}{l}\text { Rel. distr. } \\
\text { Vtrl : Drsl }\end{array}$ & $\begin{array}{l}\text { Rel. distr. } \\
\text { Left : Right }\end{array}$ & $\mathrm{P}(\%)$ & Abund. / Intensity \\
\hline $\begin{array}{l}\text { Overall Adriatic Sea sample } \\
\text { (FAO 37.2.1) }\end{array}$ & 908 & $137 \pm 8(97-180)$ & $20 \pm 5(6-45)$ & 0.8 & $\begin{array}{l}\text { A: } 0.01 \pm 0.1(0-2) \\
\text { I: } 1.1 \pm 0.4(1-2)\end{array}$ & $75: 25$ & $25: 75$ & 2.9 & $\begin{array}{l}\text { A: } 0.05 \pm 0.4(0-10) \\
\text { I: } 1.8 \pm 1.9(1-10)\end{array}$ \\
\hline $\begin{array}{l}\text { Northern Tyrrhenian Sea } \\
\text { (FAO 37.1.3) }\end{array}$ & 100 & $130 \pm 6(115-145)$ & $13 \pm 3(10-21)$ & 0 & I & / & / & 0 & / \\
\hline South Sicily (FAO 37.2.2) & 200 & $140 \pm 8(120-170)$ & $25 \pm 4(16-40)$ & 0 & I & 1 & / & 1.5 & $\begin{array}{l}\text { A: } 0.03 \pm 0.23(0-3) \\
\text { I: } 1.67 \pm 1.15(1-3)\end{array}$ \\
\hline West Sardinia (FAO 37.1.1) & 356 & $173 \pm 12(140-200)$ & $40 \pm 8(18-58)$ & 4.8 & $\begin{array}{l}\text { A: } 0.05 \pm 0.3(0-2) \\
\text { I: } 1.1 \pm 0.3(1-2)\end{array}$ & $89: 11$ & $32: 68$ & 42.4 & $\begin{array}{l}\text { A: } 0.7 \pm 1.1(0-7) \\
\mathrm{I}: 1.7 \pm 1.1(1-7)\end{array}$ \\
\hline
\end{tabular}

Abbreviations: TL - Total body length (mm); TW - Total body weight (g); P - prevalence (\%), A - Abundance given as mean \pm SD (range); I - Intensity given as mean \pm SD (range); Rel. distr. - Relative distribution (\%); Vtrl - ventral portion of fish flesh (corresponds roughly to belly flap); Drsl - dorsal portion of fish flesh 
Table 5. Sample size and basic fish host biometric data, along with basic Anisakis spp. infection parameters of blue whiting (Micromesistius pouttassou) from six different fishing areas.

\begin{tabular}{|c|c|c|c|c|c|c|c|c|c|}
\hline \multirow{2}{*}{$\begin{array}{l}\text { Sampling area } \\
\text { (ICES zone) }\end{array}$} & \multirow{2}{*}{$\begin{array}{l}\mathbf{N} \text { fish } \\
N=1534\end{array}$} & \multirow[t]{2}{*}{ TL } & \multirow[t]{2}{*}{ TW } & \multicolumn{4}{|c|}{ Musculature } & \multicolumn{2}{|c|}{ Viscera } \\
\hline & & & & $\mathrm{P}(\%)$ & $\begin{array}{l}\text { Abundance / } \\
\text { Intensity }\end{array}$ & $\begin{array}{l}\text { Rel. distr. } \\
\text { Vtrl : Drsl }\end{array}$ & $\begin{array}{l}\text { Rel. distr. } \\
\text { Left : Right }\end{array}$ & $\mathrm{P}(\%)$ & $\begin{array}{l}\text { Abundance / } \\
\text { Intensity }\end{array}$ \\
\hline $\begin{array}{l}\text { North Sea, } \\
\text { Off W Scotland } \\
\text { (ICES IVa, Vla) }\end{array}$ & 153 & $\begin{array}{l}223 \pm 43 \\
(96-333)\end{array}$ & $\begin{array}{l}68 \pm 41 \\
(5-255)\end{array}$ & 27.6 & $\begin{array}{l}\text { A: } 0.5 \pm 1.1(0-6) \\
\text { I: } 1.8 \pm 1.4(1-6)\end{array}$ & $93: 7$ & $55: 45$ & 71.1 & $\begin{array}{l}\text { A: } 7.0 \pm 10.9(0-77) \\
\text { I: } 9.9 \pm 11.7(1-77)\end{array}$ \\
\hline $\begin{array}{l}\text { Off Faroe Isles } \\
\text { (ICES Vb) }\end{array}$ & 300 & $\begin{array}{l}278 \pm 30 \\
(182-352)\end{array}$ & $\begin{array}{l}119 \pm 36 \\
(33-285)\end{array}$ & 52.3 & $\begin{array}{l}\text { A: } 6.1 \pm 11.8(0-69) \\
\text { I: } 11.7 \pm 14.2(1-69)\end{array}$ & $89: 11$ & $56: 44$ & 89.0 & $\begin{array}{l}\text { A: } 15.7 \pm 23.9(0-165) \\
\text { I: } 16.8 \pm 23.3(1-165)\end{array}$ \\
\hline $\begin{array}{l}\text { Rockall area } \\
\text { (ICES VIb) }\end{array}$ & 454 & $\begin{array}{l}324 \pm 150 \\
(225-455)\end{array}$ & $\begin{array}{l}171 \pm 77 \\
(56-558)\end{array}$ & 93.0 & $\begin{array}{l}\text { A: } 14.1 \pm 18.5(0-147) \\
\text { I: } 15.2 \pm 18.8(1-147)\end{array}$ & $90: 10$ & $46: 54$ & 98.5 & $\begin{array}{l}\text { A: } 36.4 \pm 42.4(0-309) \\
\text { I: } 37.0 \pm 42.5(1-309)\end{array}$ \\
\hline $\begin{array}{l}\text { Off Spain \& Port. } \\
\text { (ICES VIIIc, IX) }\end{array}$ & 386 & $\begin{array}{l}255 \pm 34 \\
(200-380)\end{array}$ & $\begin{array}{l}104 \pm 47 \\
(38-382)\end{array}$ & 50.5 & $\begin{array}{l}\text { A: } 2.1 \pm 5.6(0-45) \\
\text { I: } 4.1 \pm 7.3(1-45)\end{array}$ & $96: 4$ & $52: 48$ & 96.9 & $\begin{array}{l}\text { A: } 24.1 \pm 70.9(0-649) \\
\text { I: } 24.9 \pm 71.9(1-649)\end{array}$ \\
\hline $\begin{array}{l}\text { Mediterranean Sea } \\
\text { Alboran Sea }\end{array}$ & $\begin{array}{r}242 \\
69\end{array}$ & $\begin{array}{l}251 \pm 16 \\
(220-295)\end{array}$ & $\begin{array}{l}118 \pm 24 \\
(81-191)\end{array}$ & 2.9 & $\begin{array}{l}\text { A: } 0.04 \pm 0.3(0-2) \\
\text { I: } 1.5 \pm 0.7(1,2)\end{array}$ & / & / & 1.4 & $\begin{array}{l}\text { A: } 0.01 \pm 0.1(0-1) \\
\text { I: } 1 \pm 0(1)\end{array}$ \\
\hline Adriatic Sea & 172 & $\begin{array}{l}198 \pm 31 \\
(111-312)\end{array}$ & $\begin{array}{l}64 \pm 31 \\
(8-229)\end{array}$ & 34.1 & $\begin{array}{l}\text { A: } 0.8 \pm 1.5(0-8) \\
\text { I: } 2.3 \pm 1.8(1-8)\end{array}$ & $96: 4$ & $49: 51$ & 85.0 & $\begin{array}{l}\text { A: } 36.3 \pm 61.8(0-303) \\
\text { I: } 42.7 \pm 65.0(1-303)\end{array}$ \\
\hline
\end{tabular}

Abbreviations: TL - Total body length (mm); TW - Total body weight (g); P - Prevalence; A - Abundance, I - Intensity, both given as mean \pm SD (range);

Rel. distr. - Relative distribution (\%); Vtrl - ventral portion of fish flesh; Drsl - dorsal portion of fish flesh 
Table 6. Sample size and basic fish host biometric data, along with basic Anisakis infection parameters of plaice (Pp, Pleuronectes platessa) and four-spotted megrim (Lb, Lepidorhombus boscii) from eight North East Atlantic sampling localities.

\begin{tabular}{|c|c|c|c|c|c|c|c|c|c|}
\hline \multirow[t]{2}{*}{ Fishing area } & \multirow{2}{*}{$\begin{array}{l}\mathrm{N} \text { fish } \\
\text { (species) }\end{array}$} & \multirow[t]{2}{*}{$\mathrm{TL}$} & \multirow[t]{2}{*}{ TW } & \multicolumn{4}{|c|}{ Musculature } & \multicolumn{2}{|c|}{ Viscera } \\
\hline & & & & $\mathrm{P}(\%)$ & Abund. / Intensity & $\begin{array}{l}\text { Rel. distr. } \\
\text { Vtrl : Drsl }\end{array}$ & $\begin{array}{l}\text { Rel. distr. } \\
\text { Left : Right }\end{array}$ & $\mathrm{P}(\%)$ & Abund. / Intensity \\
\hline $\begin{array}{l}\text { Southern North Sea } \\
\text { (ICES IVc) }\end{array}$ & $56(\mathrm{Pp})$ & $\begin{array}{l}285 \pm 25 \\
(237-351)\end{array}$ & $\begin{array}{l}244 \pm 76 \\
(130-491)\end{array}$ & 0.0 & / & / & / & 5.4 & $\begin{array}{l}\text { A: } 0.09 \pm 0.39(0-2) \\
\text { I: } 1.67 \pm 0.58(1-2)\end{array}$ \\
\hline $\begin{array}{l}\text { English channel } \\
\text { (ICES VIId) }\end{array}$ & $184(\mathrm{Pp})$ & $\begin{array}{l}302 \pm 52 \\
(210-570)\end{array}$ & $\begin{array}{l}300 \pm 236 \\
(98-1907)\end{array}$ & 0.5 & $\begin{array}{l}\text { A: } 0.01 \pm 0.07(0-1) \\
\text { I: } 1.00 \pm 0.00(1-1)\end{array}$ & f.p. & f.p. & 12.5 & $\begin{array}{l}\text { A: } 0.15 \pm 0.42(0-3) \\
\text { I: } 1.17 \pm 0.49(1-3)\end{array}$ \\
\hline $\begin{array}{l}\text { Northern North Sea } \\
\text { (ICES IVa) }\end{array}$ & $12(\mathrm{Pp})$ & $\begin{array}{l}297 \pm 45 \\
(196-365)\end{array}$ & $\begin{array}{l}262 \pm 105 \\
(70-475)\end{array}$ & 0.0 & I & / & / & 33.3 & $\begin{array}{l}\text { A: } 3.25 \pm 6.69(0-23) \\
\text { I: } 9.75 \pm 8.92(4-23)\end{array}$ \\
\hline $\begin{array}{l}\text { Central North Sea } \\
\text { (ICES IVb) }\end{array}$ & $102(\mathrm{Pp})$ & $\begin{array}{l}294 \pm 42 \\
(220-384)\end{array}$ & $\begin{array}{l}265 \pm 116 \\
(91-540)\end{array}$ & 1.0 & $\begin{array}{l}\text { A: } 0.02 \pm 0.20(0-2) \\
\mathrm{I}: 2.00 \pm 0.00(2-2)\end{array}$ & f.p. & f.p. & 32.4 & $\begin{array}{l}\text { A: } 0.86 \pm 1.66(0-8) \\
\text { I: } 2.67 \pm 1.93(1-8)\end{array}$ \\
\hline $\begin{array}{l}\text { West of Scotland } \\
\text { (ICES VIa) }\end{array}$ & $110(\mathrm{Pp})$ & $\begin{array}{l}257 \pm 38 \\
(220-271)\end{array}$ & $\begin{array}{l}143 \pm 84 \\
(91-209)\end{array}$ & 0.9 & $\begin{array}{l}\text { A: } 0.01 \pm 0.10(0-1) \\
\mathrm{I}: 1.00 \pm 0.00(1-1)\end{array}$ & f.p. & f.p. & 42.7 & $\begin{array}{l}\text { A: } 2.94 \pm 5.28(0-28) \\
\text { I: } 6.87 \pm 6.20(1-28)\end{array}$ \\
\hline $\begin{array}{l}\text { Portuguese waters } \\
\text { (ICES IX) }\end{array}$ & 48 (Lb) & $\begin{array}{l}250 \pm 19 \\
(200-292)\end{array}$ & $\begin{array}{l}125 \pm 30 \\
(66-201)\end{array}$ & 12.5 & $\begin{array}{l}\text { A: } 0.13 \pm 0.33(0-1) \\
\mathrm{I}: 1.00 \pm 0.00(1-1)\end{array}$ & f.p. & f.p. & 45.8 & $\begin{array}{l}\text { A: } 0.65 \pm 0.86(0-4) \\
\text { I: } 1.41 \pm 0.73(1-4)\end{array}$ \\
\hline $\begin{array}{l}\text { Southwest of Ireland - East } \\
\text { (ICES VIIj) }\end{array}$ & 67 (Lb) & $\begin{array}{l}286 \pm 31 \\
(230-350)\end{array}$ & $\begin{array}{l}183 \pm 70 \\
(73-411)\end{array}$ & 65.7 & $\begin{array}{l}\text { A: } 2.19 \pm 3.04(0-16) \\
\text { I: } 3.34 \pm 3.20(1-16)\end{array}$ & $99: 1$ & $56: 44$ & 82.1 & $\begin{array}{l}\text { A: } 8.61 \pm 11.35(0-75) \\
\text { I: } 10.49 \pm 11.73(1-75)\end{array}$ \\
\hline $\begin{array}{l}\text { Southwest of Ireland - West } \\
\text { (ICES VIIk) }\end{array}$ & 72 (Lb) & $\begin{array}{l}319 \pm 33 \\
(265-485)\end{array}$ & $\begin{array}{l}232 \pm 88 \\
(133-771)\end{array}$ & 33.3 & $\begin{array}{l}\text { A: } 1.32 \pm 4.12(0-28) \\
\text { I: } 3.96 \pm 6.45(1-28)\end{array}$ & $94: 6$ & $52: 48$ & 36.1 & $\begin{array}{l}\text { A: } 1.50 \pm 3.50(0-19) \\
\text { I: } 4.15 \pm 4.83(1-19)\end{array}$ \\
\hline $\begin{array}{l}\text { Bay of Biscay } \\
\text { (ICES VIII) }\end{array}$ & 100 (Lb) & $\begin{array}{l}243 \pm 24 \\
(200-315)\end{array}$ & $\begin{array}{l}112 \pm 37 \\
(62-232)\end{array}$ & 12.0 & $\begin{array}{l}\text { A: } 0.17 \pm 0.49(0-2) \\
\text { I: } 1.42 \pm 0.51(1-2)\end{array}$ & $88: 12$ & $29: 71$ & 46.0 & $\begin{array}{l}\text { A: } 1.36 \pm 3.05(0-21) \\
\text { I: } 2.96 \pm 3.96(1-21)\end{array}$ \\
\hline
\end{tabular}

Abbreviations: TL - Total body length (mm); TW - Total body weight (g); P - prevalence (\%), A - Abundance, I - Intensity, both given as mean \pm SD (range); Rel. distr. Relative distribution (\%); Vtrl - ventral portion of fish flesh (corresponds roughly to belly flap); Drsl - dorsal portion of fish flesh; f.p. - too few parasites for appropriate calculation 
Click here to download high resolution image

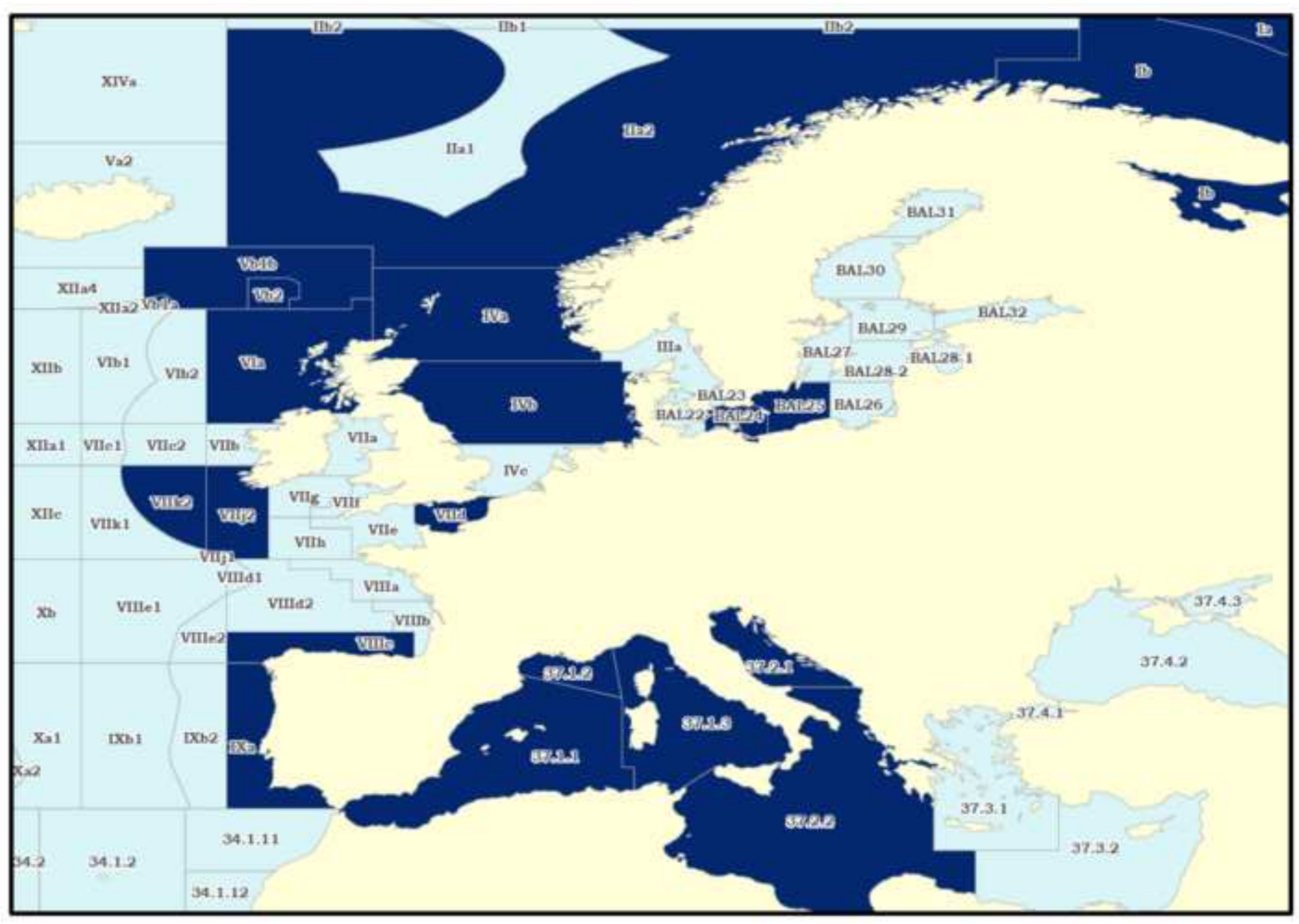


Click here to download high resolution image

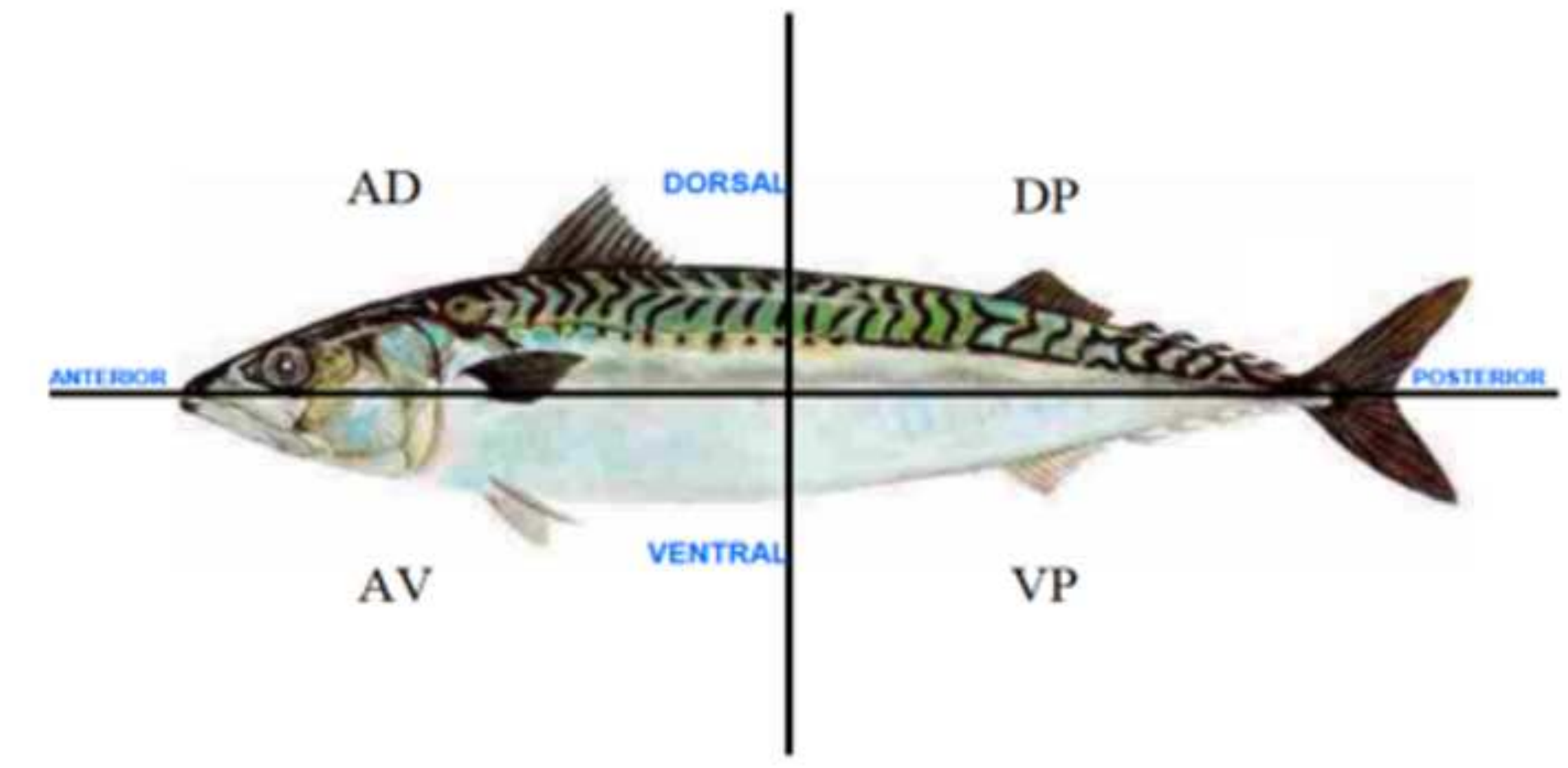

\section{click here to download high resolution image}


Figure3-UV image of fish fillets
Click here to download high resolution image

\section{Left flesh side}

Right flesh side

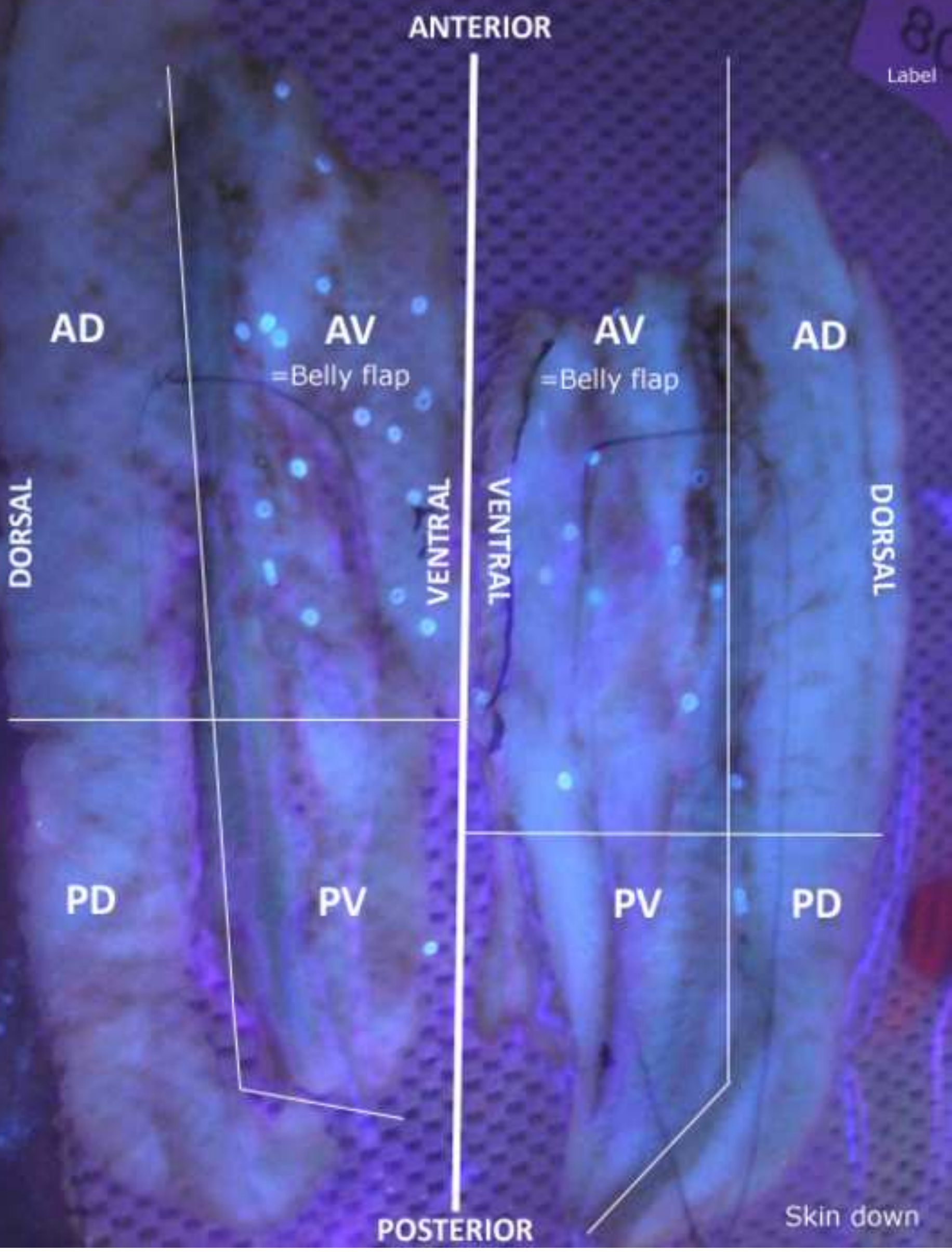



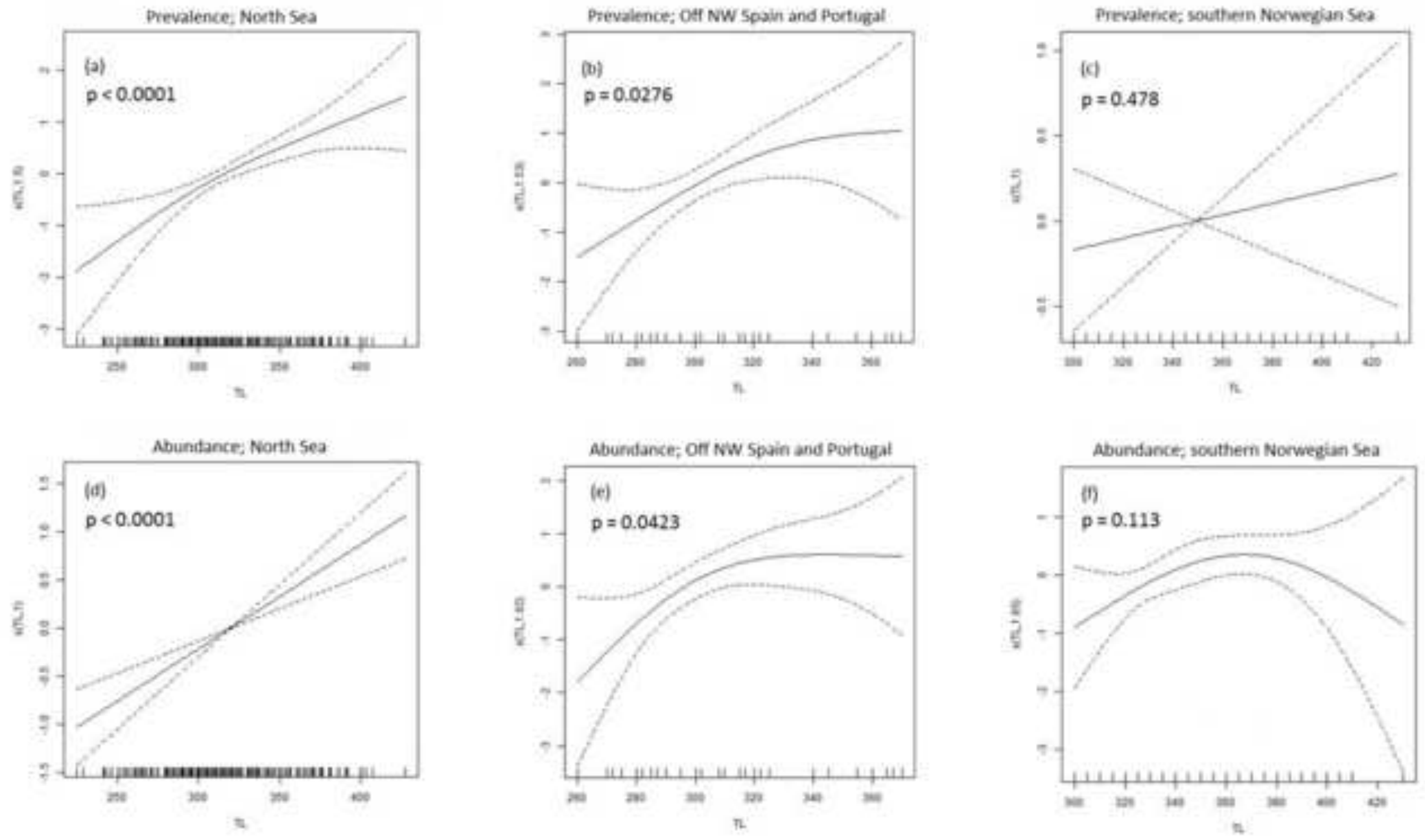

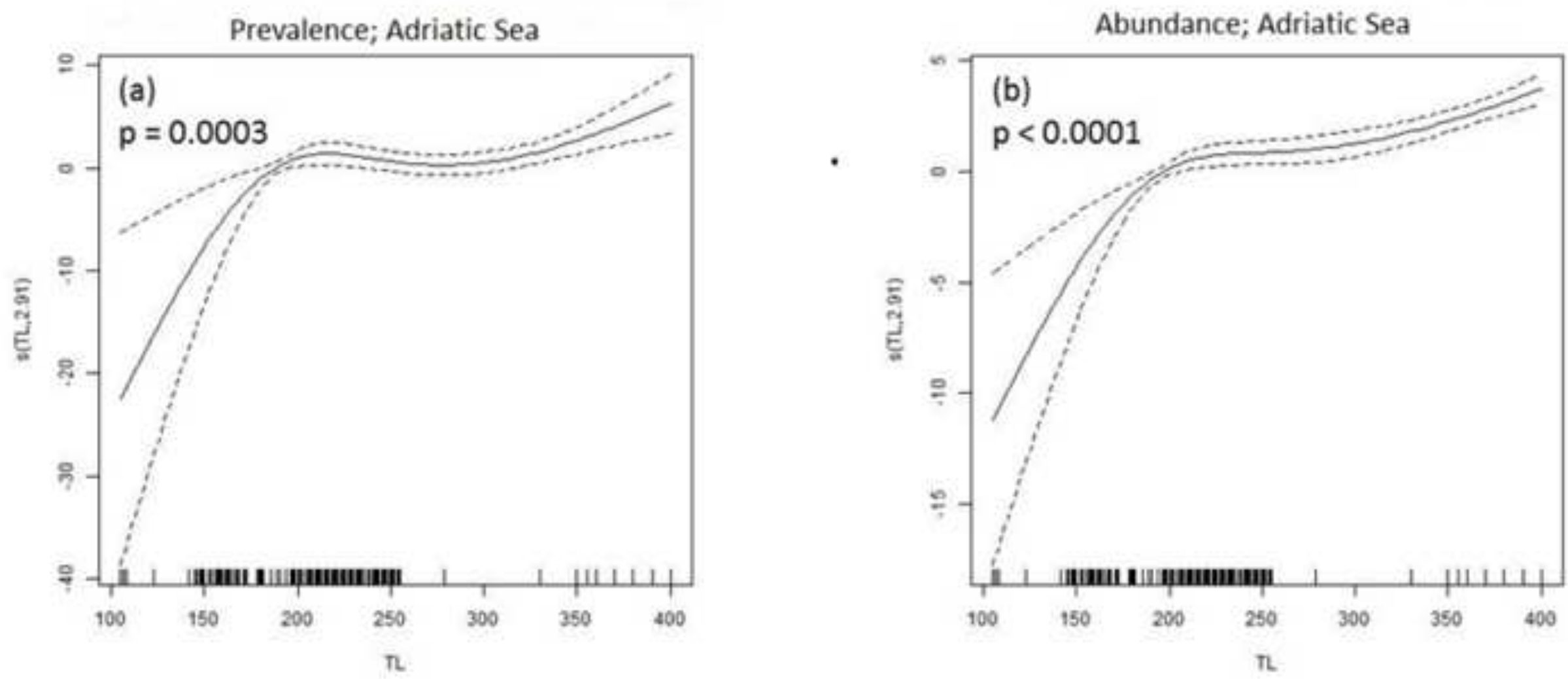

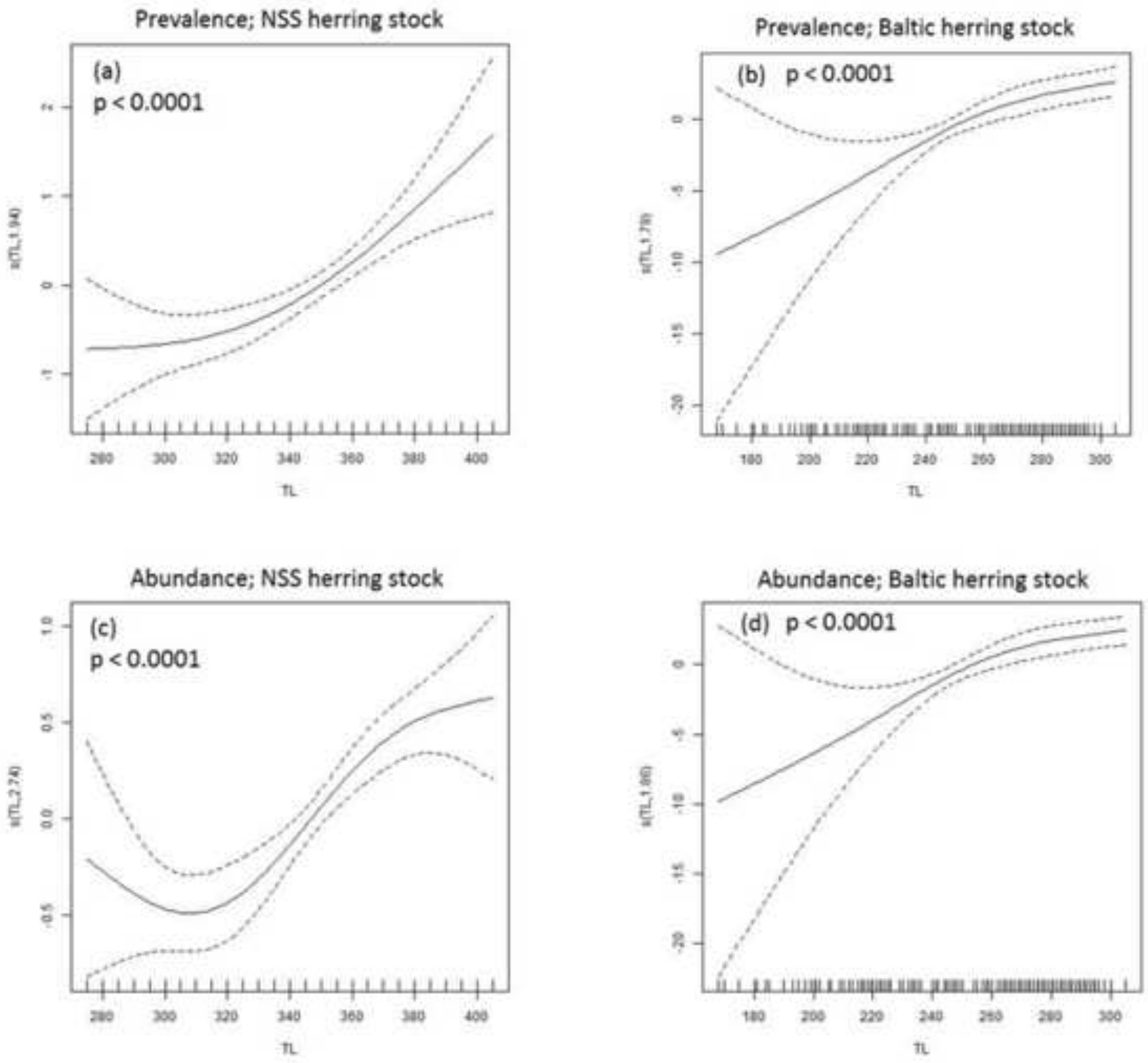

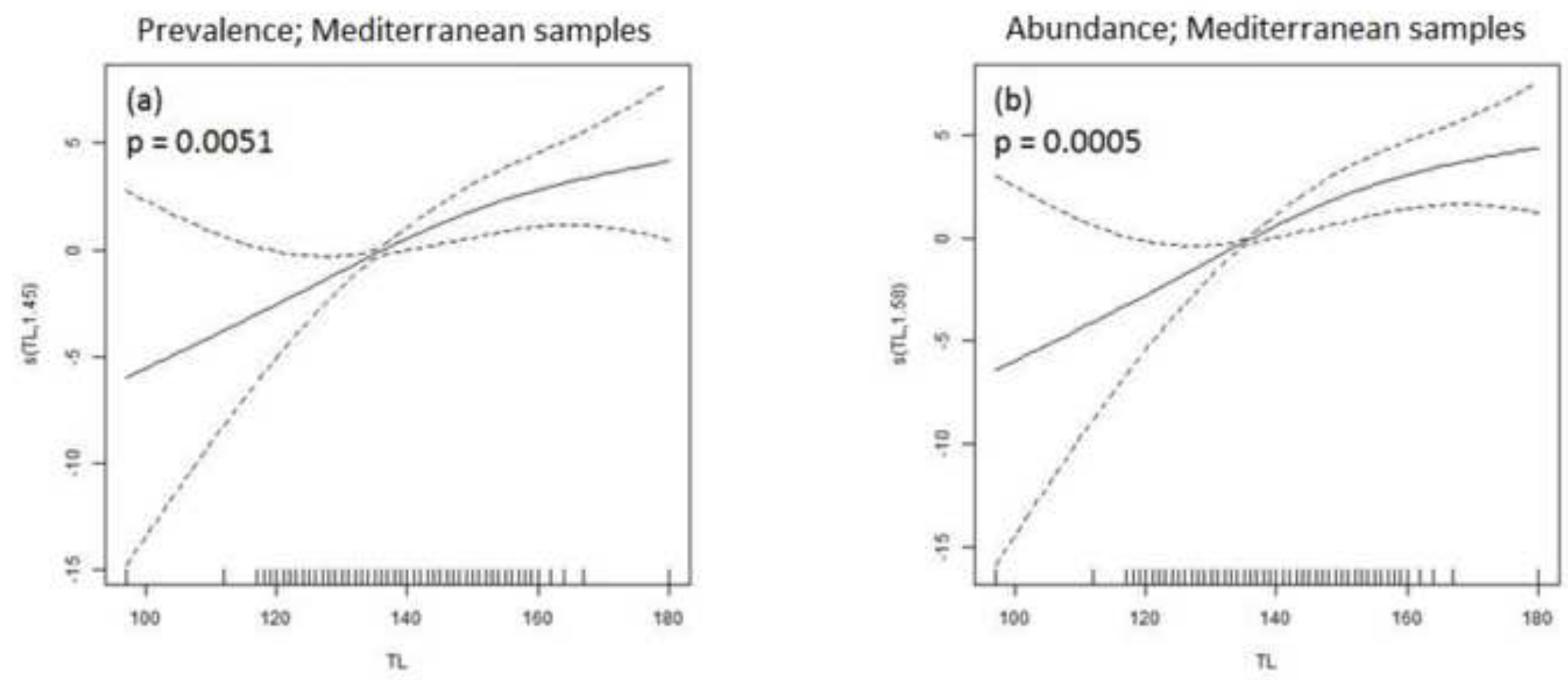

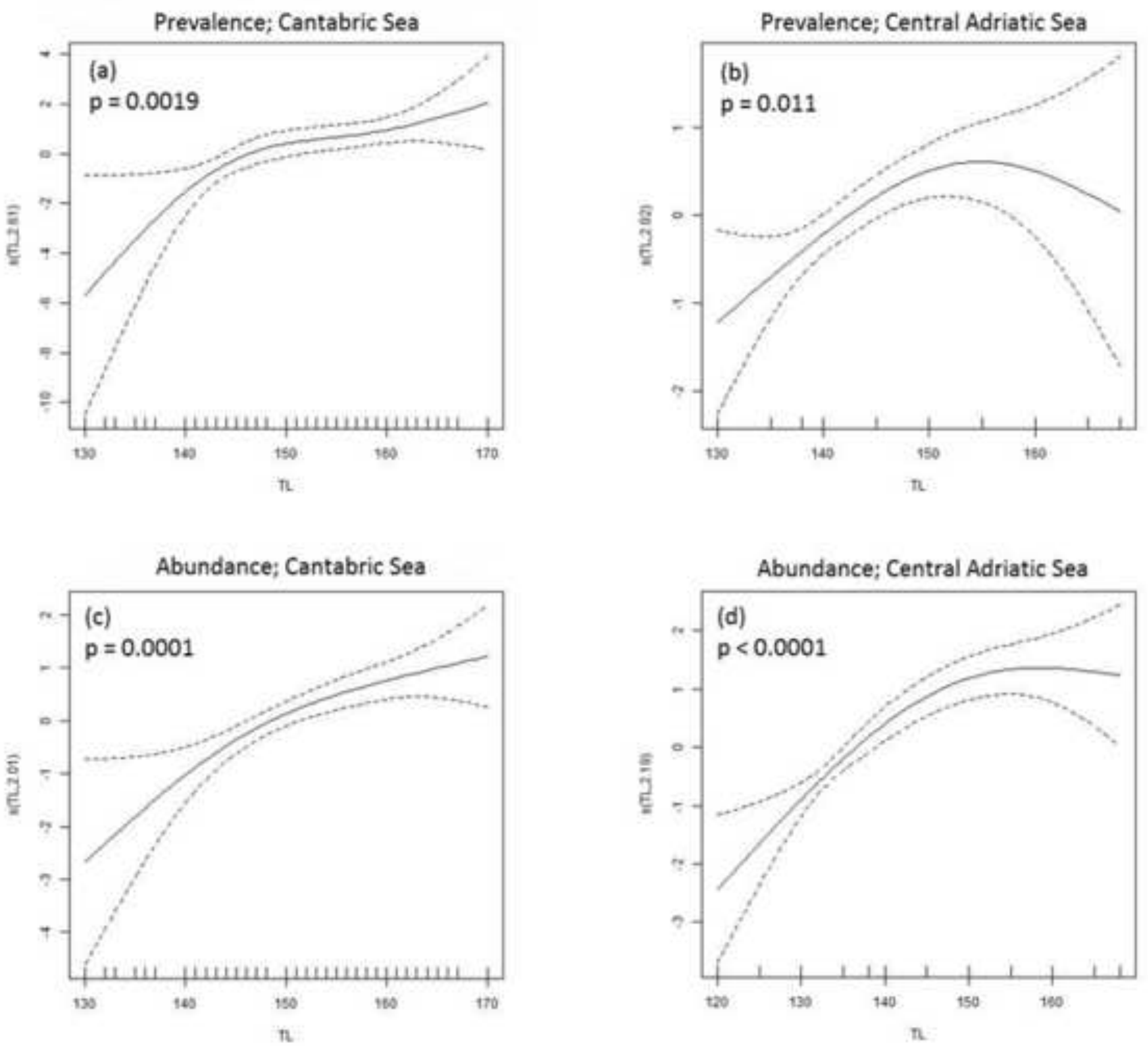
Click here to download high resolution image
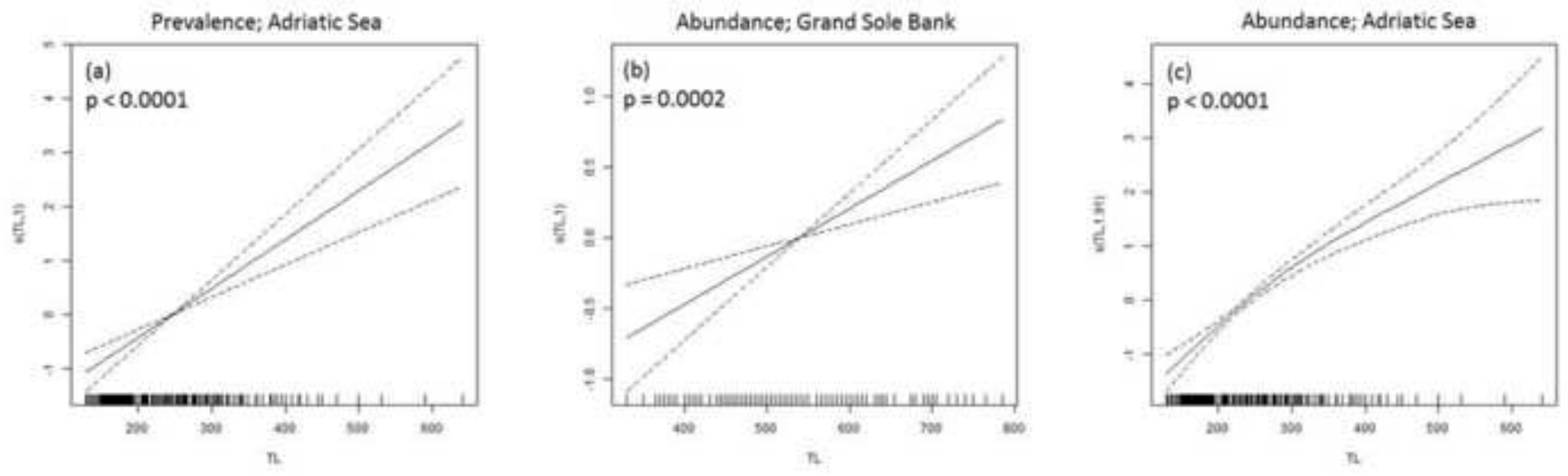


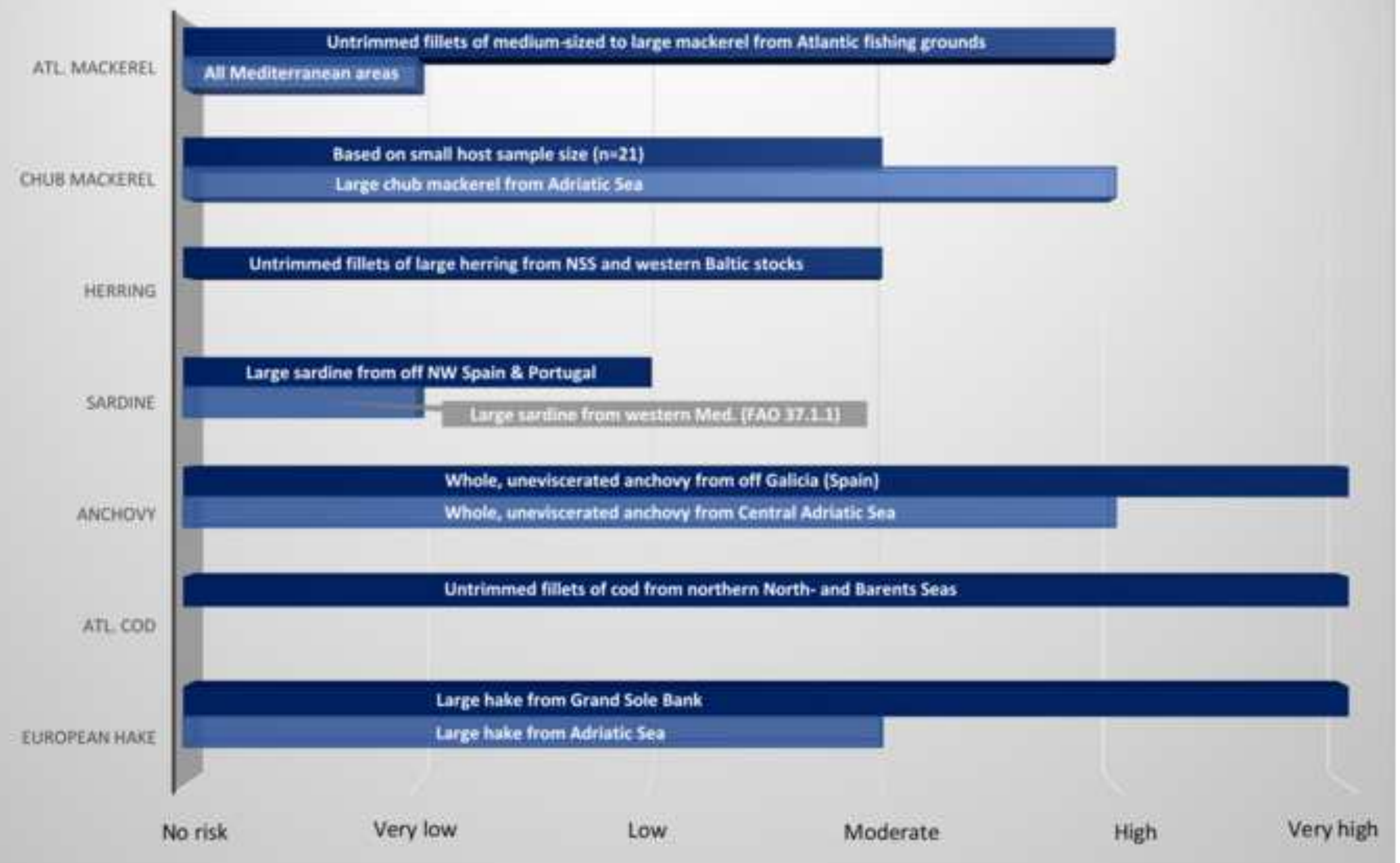

